\title{
QTLs Identified for Biofortification Traits in Wheat: A Review
}

\author{
Pooja Devi ${ }^{1}$, Prashant Kaushik ${ }^{2 *}$, Dinesh Kumar Saini ${ }^{1}$ \\ 1. Department of Plant Breeding and Genetics, Punjab Agricultural University, Ludhiana 141004, India \\ 2. Instituto de Conservación y Mejora de la Agrodiversidad Valenciana, Universitat Politècnica de València, 46022 \\ Valencia, Spain \\ * Correspondence: prakau@ doctor.upv.es
}

\begin{abstract}
Wheat is the essential constituent of cereal-based diets and one of the most significant sources of calories. However, there is an inherently low bioavailability of proteins, mineral, and vitamins in modern wheat grains. Biofortification has earned recognition as an outstanding approach, at the same time as a cure for world hunger. The developments in the identifications of quantitative trait loci (QTL) analysis and understanding of the physiological and molecular basis of QTLs controlling the biofortification traits in wheat has revealed new horizons for the improvement of modern wheat varieties. Within this review, we have compiled the information from the studies carried out in wheat using QTL mapping methodologies that is among the best methods for biofortification traits. We hope this review will serve as an essential reference for the QTLs identified for the several important biofortification traits in wheat.
\end{abstract}

Keywords: wheat; biofortification; QTLs; protein; minerals

\section{Introduction}

Malnutrition impacts more than two billion individuals, and Asia and Africa are the most affected regions [1]. Biofortification is an approach for improving the levels of vital ingredients like vitamins, minerals and proteins in the edible portions of crops through conventional breeding, biotechnological and genomics approaches [2,3]. Although minerals and vitamins are commonly provided as the dietary supplements, they are out of the reach of most of the people living in the third world [4,5]. Biofortification is a one-time expense that provides a cost-effective, long-term, and sustainable method in combating concealed starvation [6]. People are mostly dependent on the supply of cereals for their dietary requirements; therefore, biofortification of cereals is essential [7]. Wheat is globally traded more than any other crop, and it is the second most produced cereal next to maize [8].

Moreover, wheat annual production has almost tripled since 1940s, and it is anticipated that the yield increment trend of wheat will continue [9]. The biofortified wheat will be useful for the starvation-related malnutrition issue faced primarily by the reduced earnings nations [10].

Large variation for grain iron and zinc concentrations is found in the wild relatives like Aegilops tasuchii of wheat and continues to be exploited for enhancement of modern elite cultivars [11]. Provitamin A continues to be an additional essential nutrient focused for biofortification in wheat via breeding. Accessions of durum wheat are higher in provitamin concentration, and yellow pigment content material due to the presence of carotenoids (xanthophyll and lutein) in durum wheat is an essential trait for improving the content of antioxidant in wheat cultivars $[12,13,14]$. Similarly, enhancement of anthocyanins content in wheat has also an important focus of wheat biofortification programs. Coloured wheat (black, blue, and purple) trait due to the high concentration of phenolics continues to be utilized in several breeding programs and varieties are already released in several nations $[3,15,16]$.

Several agronomic methods can lead to wheat biofortification [17]. However, augmenting mineral concentrations exclusively via agronomic practices such as foliar sprays indicate high expenses for farmers [18]. Next-generation sequencing is proving useful in the determination of the precise information of cultivated crops. Moreover, developments in next-generation sequencing and statistical methods can aid the identification of the regions within the wheat genome responsible for higher mineral and vitamin content $[19,20,21]$. QTL or linkage mapping methods are employed when the mapping populations are established [22, 23]. Biofortification by breeding continues to be accomplished in crops when genetic variability is readily accessible from the primary, secondary, or tertiary gene pool of crop. When genetic variability is unavailable or difficult to exploit, the genetic transformation is the better approach [24]. Wheat has a large number of wild relatives 
that could contribute to underexploited wild relatives $[25,26]$. The different steps involved in the development of biofortification wheat with the aid of marker-assisted breeding are presented in Figure 1.

\section{Genetic Biofortification of Wheat}

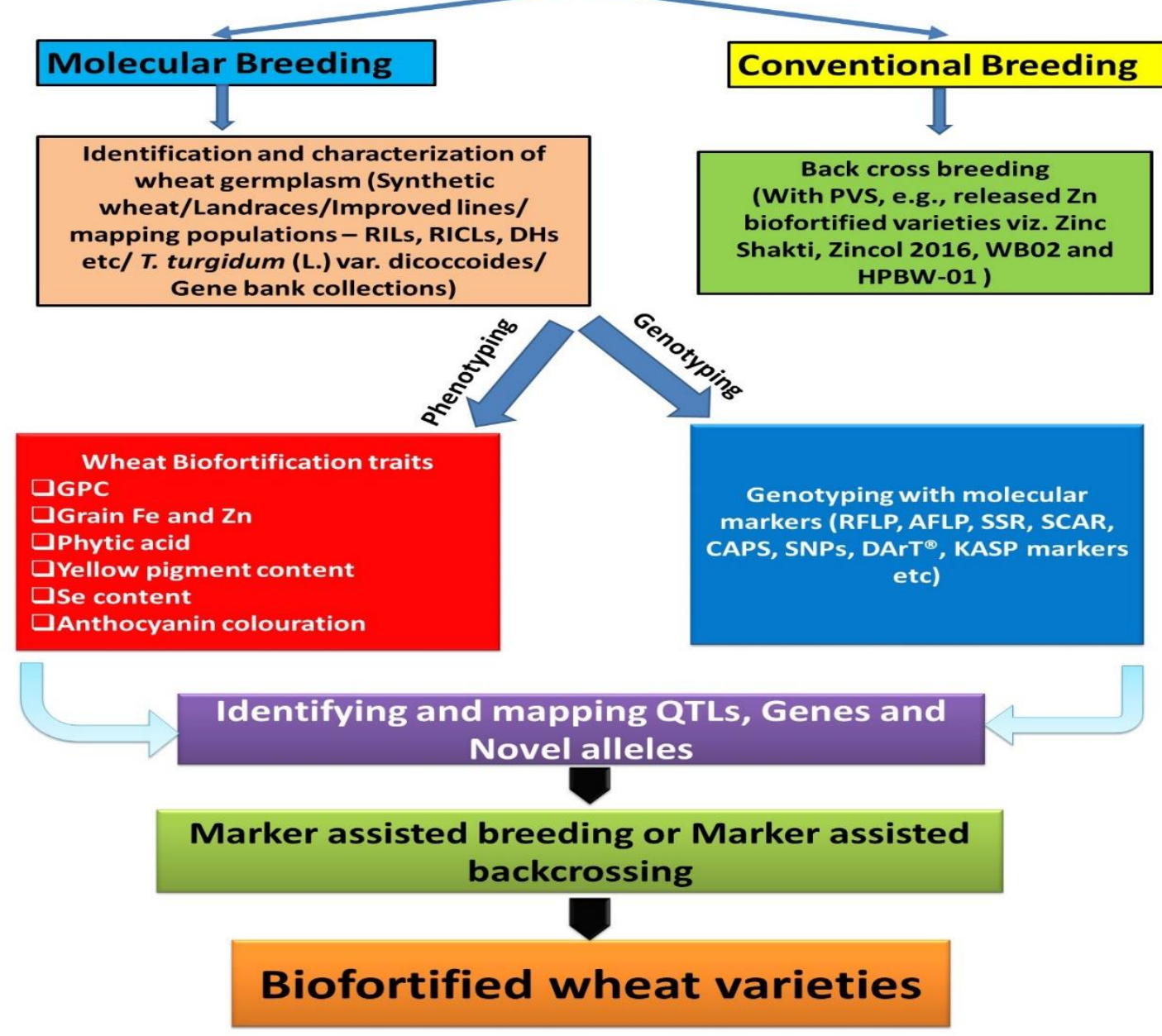

Figure 1. Representation of different strategies for biofortification of the wheat, especially explaining different steps of marker-assisted breeding.

Conventional breeding methods are easy to operate with qualitative traits. These traits depend on a single gene whereas traits like yield are quantitative and therefore are impacted by several genes [27, 28, 29]. There are several techniques for mapping quantitative trait loci (QTL) in an experimental cross [30]. The molecular basis of QTLs is challenging to dissect, even for model plants like Arabidopsis and rice, because of the problems in precisely narrowing intervals to single genes [31]. Experimental design, type of plant population analysed and the level of polymorphisms between parental genomes also affect the predictions of QTLs. Statistical methods to determine quantitative trait loci (QTL) require numerous molecular markers with high-resolution genetic maps [32, 33]. This approach is also related to genomics methods which are geared toward the dissection of complex phenotypes [34].

Genomic resources of wheat have provided important support for functional genomics and conservation biology (by conserving the important landraces) [35, 36]. The wheat genome is complex to interpret simply because of broadly dispersed repetitive sequences, heterozygosity, and polyploidy [37, 38]. Nevertheless, the developments in sequencing methodologies, decreased sequencing price, together with the advancements in the computational resources have permitted the spread of these resources [39, 40]. Besides, the comparative genomics among plant species is demonstrating to be an efficient method for the identification of novel genes regarding the biofortification of modern wheat [41]. Therefore, in this review, we have compiled the QTLs 
identified for protein and amino acids, mineral elements and pigments like anthocyanin. This review will be a useful and important resource for the wheat breeders to refer to consider the biofortification of modern wheat.

\section{Biofortification for Grain Protein Content}

Grain protein content (GPC) is among the important traits that contribute to the nutritional value, processing preference, quality of the end products (bread and pasta) and market value of both the hexaploid (Triticum aestivum L.) and durum (T. turgidum L. var. durum Desf.) wheat. Based on the extraction methods, grain proteins are grouped into four groups, albumins, globulins, prolamins, and glutelins. The economic value of the wheat grains rely on the GPC; therefore, improvement in GPC and alteration in the composition of storage proteins in wheat grain have been a significant objective in wheat breeding programs, particularly for those working toward raising the nutritional quality [42]. Attempts have been made by breeders for improvement in GPC using conventional breeding methods, but the desired outputs are not obtained. The reasons for this include (1) high influence of environment on GPC, (2) negative correlation between GPC and grain yield, and (3) quantitative genetic control of GPC and low heritability [43]. The QTLs for GPC have been identified and mapped on almost all chromosomes of both tetraploid and hexaploid wheat. To our knowledge, for GPC a total of 325 main effect QTL have been reported so far using biparental populations (Table 1). Here, we listed the closely linked markers or marker intervals for the significant QTLs (PVE>10), which may be useful to introgress the target QTLs in elite lines (Table 1). Although major QTLs with a stable effect on GPC across environments are also identified, most of the identified major QTLs were found unstable across the environments. 
Table 1. List of quantitative trait loci (QTL) identified for grain protein content.

\begin{tabular}{|c|c|c|c|c|c|c|}
\hline Cross & $\begin{array}{l}\text { Populatio } \\
\text { n type } \\
\text { and size }\end{array}$ & $\begin{array}{l}\text { No. of } \\
\text { total } \\
\text { QTLs }\end{array}$ & $\begin{array}{c}\text { PVE range } \\
\text { (additive } \\
\text { effect } \\
\text { QTLs) } \\
\end{array}$ & $\begin{array}{l}\text { Chromosomes/ } \\
\text { chromosome arms }\end{array}$ & Marker intervals / nearest markers for major QTL (PVE) & References \\
\hline \multicolumn{7}{|l|}{ Durum wheat } \\
\hline $\begin{array}{l}\text { ('Messapia) } \times T \text {. } \\
\text { turgidum L. var. } \\
\text { dicoccoides } \\
\text { (MG4343) }\end{array}$ & RILs (65) & 6 & $6.6-27.7$ & $\begin{array}{c}\text { 4BS, 5AL, 6AS, } \\
\text { 6BS, 7BS }\end{array}$ & - & {$[44]$} \\
\hline $\begin{array}{l}\text { T. turgidum (L.) var. } \\
\text { dicoccoides } \\
\text { chromosome } 6 \mathrm{~B}\end{array}$ & $\begin{array}{l}\text { RICLs } \\
(85)\end{array}$ & 1 & 66 & $6 \mathrm{BS}$ & Xabg387-6B-Xmwg79-6B (66) & {$[45]$} \\
\hline \multicolumn{7}{|l|}{ T. aestivum (PH132) } \\
\hline $\begin{array}{l}\times \text { T. aestivum } \\
\text { (WL711) }\end{array}$ & RILs(100) & 1 & 18.73 & 2DL & wmc41 (18.73) & [46] \\
\hline $\begin{array}{c}\text { T. aestivum } \\
\text { (Courtot) } \times T \text {. } \\
\text { aestivum }(\text { Chinese } \\
\text { Spring) }\end{array}$ & $\begin{array}{l}\text { DH lines } \\
\quad(187)\end{array}$ & 2 & 7.0-17.0 & $1 \mathrm{~B}, 6 \mathrm{~A}$ & XE38M60200 (17) & [47] \\
\hline $\begin{array}{l}\text { T. aestivum (PH132) } \\
\times \text { T. aestivum } \\
\text { (WL711) }\end{array}$ & $\begin{array}{l}\text { RILs } \\
(106)\end{array}$ & 9 & $2.9-7.2$ & 2BL, 7AS & - & [48] \\
\hline \multicolumn{7}{|l|}{ T. aestivum (PH132) } \\
\hline $\begin{array}{l}\times T . \text { aestivum } \\
\quad \text { (WL711) }\end{array}$ & & 1 & 6.2 & $5 \mathrm{AL}$ & - & [49] \\
\hline $\begin{array}{l}\text { Durum wheat } \\
\text { (Messapia) } \times T \text {. } \\
\text { turgidum var. } \\
\text { dicoccoides } \\
\text { (MG4343) }\end{array}$ & RILs (65) & 7 & $6.5-31.7$ & $\begin{array}{l}4 \mathrm{BS}, 5 \mathrm{AL}, 6 \mathrm{~A}, 6 \mathrm{BS} \\
\text { 7AS, 7BS) }\end{array}$ & $\begin{array}{c}\text { Xpsr627 (10.2), Xutv913 (12.6), Pan2 (14.8), Xcdo412 (14.9), Xpsr167 } \\
\text { (18.4), Gai-1 (31.7) }\end{array}$ & [50] \\
\hline $\begin{array}{c}\text { T. aestivum (Opata } \\
85) \times \text { synthetic } \\
\text { hexaploid wheat } \\
\text { (W7984) }\end{array}$ & $\begin{array}{l}\text { RILs } \\
(114)\end{array}$ & 2 & & 2DS, 7AS & - & [51] \\
\hline
\end{tabular}




\begin{tabular}{|c|c|c|c|c|c|c|}
\hline $\begin{array}{l}\text { T. aestivum (Renan) } \\
\quad \times T \text {. } \\
\text { aestivum (Récital) }\end{array}$ & $\begin{array}{l}\text { RILs } \\
\text { (194) }\end{array}$ & 10 & 4.1-10.4 & $\begin{array}{c}\text { 1A, 2AS, 3AL, } \\
\text { 3BS, 4AS, 4DL, } \\
\text { 5BL, 6AL, 7AS, } \\
\text { 7DL }\end{array}$ & - & {$[52]$} \\
\hline $\begin{array}{l}\text { T. aestivum } \\
(\text { WL711) } \times T \text {. } \\
\text { aestivum }(\mathrm{PH} 132)\end{array}$ & $\begin{array}{l}\text { RILs } \\
(100)\end{array}$ & 13 & $2.95-32.44$ & $\begin{array}{l}\text { 2AS, 2BL, 2DL, } \\
\text { 3DS, 4AL, 6BS, } \\
\quad 7 \mathrm{AS}, 7 \mathrm{DS}\end{array}$ & $\begin{array}{c}\text { Xgwm1249 (13.39), Xgwm894 (13.36), Xgwm1264 (13.83), Xgwm892 } \\
\text { (13.99), Xgwm456 (16.27), Xgwm133 (16.38), Xgwm830 (20.75), } \\
\text { Xgwm1171 (32.44) }\end{array}$ & {$[53]$} \\
\hline $\begin{array}{l}\text { T. turgidum (L.) var. } \\
\text { dicoccoides } \\
{[\text { LDN(Dic-5B)] }} \\
\text { LDN }\end{array}$ & $\begin{array}{l}\text { RICLs } \\
(133)\end{array}$ & 3 & $10.0-33.0$ & (1) & Xbcd1030-Xgwm604 (32), Xcdo584-Xabc310 (33) & [54] \\
\hline $\begin{array}{l}\text { T. aestivum (Renan) } \\
\quad \times T \text {. } \\
\text { aestivum (Récital) }\end{array}$ & $\begin{array}{l}\text { RILs } \\
(194)\end{array}$ & 3 & $6.2-9.6$ & $3 \mathrm{~A}, 4 \mathrm{D}, 7 \mathrm{D}$ & & {$[55]$} \\
\hline $\begin{array}{c}\text { T. aestivum } \\
\text { (WL711) } \times T . \\
\text { aestivum }(\mathrm{PH} 132)\end{array}$ & $\begin{array}{l}\text { RILs } \\
\text { (100); } \\
\text { RILs } \\
(110)\end{array}$ & $7+26$ & $8.38-16.58$ & $\begin{array}{l}\text { 1AS, 1BL, 1DL, } \\
\text { 2AS, 2AL, 2BL, } \\
\text { 2DS, 2DL, 3BS, } \\
\text { 4AS, 5BL, 5DL, } \\
\text { 6DL, 7AL, 7DS }\end{array}$ & $\begin{array}{l}\text { Xgwm126-Xmwg2112 (10.45), Xbcd1261-XksuE11 (10.49), Xgwm497- } \\
\text { Xgwm614 (10.73), Xfbb260-Xfbb250 (13.59), Xcdo1379-Xbcd262 } \\
\text { (14.25), Xcdo1379-Xbcd262 (15.22), Xgwm102-Xcdo405 (16.58) }\end{array}$ & {$[56]$} \\
\hline $\begin{array}{l}\text { Canadian Spring } \\
\text { wheat (AC Karma) } \\
\times T \text {. aestivum } \\
(87 \mathrm{E} 03-\mathrm{S} 2 \mathrm{~B} 1)\end{array}$ & $\begin{array}{l}\text { DH lines } \\
(185)\end{array}$ & 2 & $12.6-32.7$ & $4 \mathrm{D}, 7 \mathrm{~B}$ & Xwmc662 (12.6), Xwmc52 (32.7) & {$[57]$} \\
\hline $\begin{array}{c}T . \\
\text { aestivum (Opata85) } \\
\times \text { Synthetic } \\
\text { hexaploid wheat } \\
\text { (W7984) }\end{array}$ & 114 RILs & 4 & $15.0-32.0$ & $\begin{array}{l}\text { 2AL, 2DS, 5AL, } \\
\text { 6DS }\end{array}$ & $\begin{array}{c}\text { Xbcd152-Xfbb329 (15), Xfba85-Xgwm469 (16), Xcdo1312-Xabg391 } \\
\text { (19), Xbcd102-Xbcd18 (32), }\end{array}$ & [58] \\
\hline $\begin{array}{l}\text { T. aestivum (Arche) } \\
\quad \times \text { T. aestivum } \\
\quad \text { (Recital) }\end{array}$ & $\begin{array}{l}\text { DH lines } \\
(222)\end{array}$ & 13 & $5.5-24.7$ & $\begin{array}{l}1 \mathrm{~B}, 2 \mathrm{AS}, 2 \mathrm{AL}, 2 \mathrm{DS} \\
3 \mathrm{~B}, 3 \mathrm{D}, 4 \mathrm{~B}, 5 \mathrm{~A}, 5 \mathrm{~B} \\
\quad 7 \mathrm{D}\end{array}$ & $\underset{(24.7)}{c}$ & {$[59]$} \\
\hline $\begin{array}{l}\text { T. aestivum (Chuan } \\
35050) \times T \text {. } \\
\text { aestivum (Shannong } \\
\text { 483) }\end{array}$ & $\begin{array}{l}\text { RILs } \\
(131)\end{array}$ & 3 & $8.64-21.23$ & 3BL, 5AL, 6AS & Xwmc418-Xubc834a (13.34), Xsrap27-Xwmc524 (21.23) & {$[60]$} \\
\hline $\begin{array}{l}\text { T. aestivum } \\
\text { (Neixiang188) } \times T \\
\text { aestivum (Yanzhan) }\end{array}$ & $\begin{array}{l}\text { RILs } \\
(198)\end{array}$ & 16 & $3.2-14.5$ & $\begin{array}{l}1 \mathrm{~B}, 2 \mathrm{~A}, 2 \mathrm{~B}, 3 \mathrm{~A}, 3 \mathrm{~B} \\
4 \mathrm{D}, 5 \mathrm{~B}, 5 \mathrm{D}, 7 \mathrm{~B}, 7 \mathrm{D}\end{array}$ & cwm13-wms71b (12), wmc3-wmc418 (14.5) & {$[61]$} \\
\hline
\end{tabular}




\begin{tabular}{|c|c|c|c|c|c|c|}
\hline $\begin{array}{l}\text { T. aestivum (kukri) } \\
\times \text { T. aestivum }(\mathrm{Janz})\end{array}$ & $\begin{array}{l}\text { DH lines } \\
\quad(160)\end{array}$ & 13 & & $\begin{array}{c}1 \mathrm{~B}, 2 \mathrm{~A}, 3 \mathrm{AS}, 3 \mathrm{~B} \\
4 \mathrm{~B}, 4 \mathrm{D}, 5 \mathrm{~A}, 5 \mathrm{~B}, 7 \mathrm{AL} \\
7 \mathrm{D}\end{array}$ & & {$[62]$} \\
\hline $\begin{array}{l}\text { Indian durum wheat } \\
\text { (PDW 233) } \times \\
\text { Bhalegaon } 4(\mathrm{a} \\
\text { landrace })\end{array}$ & $\begin{array}{l}\text { RILs } \\
(140)\end{array}$ & 1 & 9.64 & 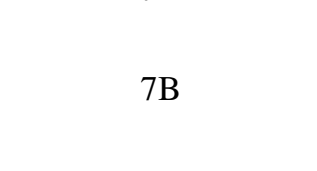 & - & {$[63]$} \\
\hline $\begin{array}{l}\text { Durum wheat } \\
\text { (Langdon) } \times \text { Wild } \\
\text { emmer accession } \\
\quad(\text { G18-16) }\end{array}$ & $\begin{array}{l}\text { RILs } \\
(152)\end{array}$ & 10 & $2.8-9.7$ & $\begin{array}{l}\text { 2AL, 2BL, 3BL, } \\
4 \mathrm{AL}, 5 \mathrm{AS}, 5 \mathrm{BL} \\
6 \mathrm{AS}, 6 \mathrm{BL}, 7 \mathrm{AL} \\
\quad 7 \mathrm{BS}\end{array}$ & - & [64] \\
\hline $\begin{array}{l}\text { T. aestivum (Chara) } \\
\times \text { an advanced } \\
\text { breeding line } \\
\text { (WW2449) }\end{array}$ & $\begin{array}{l}\text { DH lines } \\
\text { (190) }\end{array}$ & 1 & 20 & $4 \mathrm{~A}$ & Xstm506tgag-Xgwm165b (20) & {$[65]$} \\
\hline $\begin{array}{l}\text { Durum breeding line } \\
\text { (DT695) } \times \text { Durum } \\
\text { wheat cultivar } \\
\text { (Strongfield) }\end{array}$ & $\begin{array}{l}\text { DH lines } \\
(185)\end{array}$ & 9 & & $\begin{array}{c}1 \mathrm{~A}, 1 \mathrm{~B}, 2 \mathrm{AS}, 2 \mathrm{BL} \\
5 \mathrm{~B}, 6 \mathrm{~B}, 7 \mathrm{AL}, 7 \mathrm{~B}\end{array}$ & - & {$[66]$} \\
\hline $\begin{array}{l}\text { Chinese hard wheat } \\
\text { line }(\text { Ning7840) } \times \\
\text { Soft wheat cultivar } \\
\quad(\text { Clark })\end{array}$ & $\begin{array}{l}\text { RILs } \\
\text { (132) }\end{array}$ & 2 & $11.2-16.8$ & 3AS, 4B & Xwmc749-Xgwm369 (11.2), Xgwm368-Xwmc617 (16.8) & {$[67]$} \\
\hline $\begin{array}{c}\text { T. aestivum } \\
\text { (MN98550) } \times \text { T. } \\
\text { aestivum }(\text { MN99394) }\end{array}$ & $\begin{array}{l}\text { RILs } \\
\text { (139) }\end{array}$ & 3 & $4.5-16.8$ & 2BS, 5AL, 6DL & Xbarc330-XwPt9094 (11.1), Xwmc245-Xgwm271 (16.8) & {$[68]$} \\
\hline $\begin{array}{l}\text { T. aestivum (Huapei } \\
\text { 3) } \times \text { T. aestivum } \\
\text { (Yumai 57) }\end{array}$ & $\begin{array}{l}\text { DH lines } \\
(168)\end{array}$ & 4 & $3.09-8.40$ & $3 \mathrm{~A}, 3 \mathrm{~B}, 5 \mathrm{D}, 6 \mathrm{D}$ & - & {$[69]$} \\
\hline $\begin{array}{l}\text { Durum breeding line } \\
(\text { C1113 }) \times \text { Durum } \\
\text { cultivar }(\text { Kofa })\end{array}$ & RILs (93) & 15 & 9.3-21.6 & $\begin{array}{l}\text { 1BS, 2AL, 2BS, } \\
\text { 3BS, 3BL, 4AL, } \\
\text { 5AS, 5BL, 7AS, } \\
\quad 7 \mathrm{BL}\end{array}$ & $\begin{array}{c}\text { wmc168-barc219 (12.7), gwm273-wmc626 (13.3), cfd50-gdm93 (14.1), } \\
\text { gwm499-BE495277_339 (14.6), barc1073-barc340 (15.6), dupw4- } \\
\text { barc170 (16.6), wmc597-BM140538_39 (20.8), barc101-barc117 (21), } \\
\text { barc147-gwm493 (21.6) }\end{array}$ & {$[70]$} \\
\hline $\begin{array}{l}\text { Svevo } \times \text { Ciccio } \\
\text { (both elite durum } \\
\text { wheat cultivars) }\end{array}$ & $\begin{array}{l}\text { RILs } \\
(120)\end{array}$ & 11 & $7.8-40.2$ & $\begin{array}{l}\text { 1AS, } 1 \mathrm{AL}, 2 \mathrm{AS} \\
\text { 2BL, 3BS, 4AL, } \\
\text { 4BL, } 5 \mathrm{AL}, 6 \mathrm{BS} \\
\quad 7 \mathrm{BL}\end{array}$ & $\begin{array}{c}\text { Xgwm330-D_379033 (13.1), BJ236800-Xbarc68 (13.5), BQ607256- } \\
\text { TC87195a (13.8), D_310555-Xgwm251 (13.9), Xwmc630b-Xwmc453 } \\
\text { (14.8),TC82001-Xgwm372c (16.2), D_376852-Xgwm601 (17.6), } \\
\text { Xgwm633-CA594434a (18.7), D_304657-Xwmc332 (20.4), D_521287- } \\
\text { Xgwm389 (40.2), }\end{array}$ & [71] \\
\hline
\end{tabular}




\begin{tabular}{|c|c|c|c|c|c|c|}
\hline $\begin{array}{c}\text { Oste-Gata } \times \\
\text { Massara-1 (durum } \\
\text { wheat genotypes) }\end{array}$ & $\begin{array}{l}\mathrm{F} 2 \text { derived } \\
\mathrm{F} 3 \text { and } \mathrm{F} 4 \\
\text { lines }(151)\end{array}$ & 2 & $5.31-9.44$ & $1 \mathrm{~A}, 5 \mathrm{BL}$ & - & {$[72$} \\
\hline $\begin{array}{l}\text { T. aestivum (Weimai } \\
8) \times \text { T. aestivum } \\
\text { (Jimai 20) }\end{array}$ & $\begin{array}{l}\text { RILs } \\
(485)\end{array}$ & 9 & $3.06-9.79$ & $\begin{array}{c}2 \mathrm{~B}, 3 \mathrm{~A}, 4 \mathrm{~A}, 4 \mathrm{D}, 5 \mathrm{~B} \\
7 \mathrm{~A}, 7 \mathrm{~B}\end{array}$ & - & {$[73$} \\
\hline $\begin{array}{l}\text { T. aestivum (Weimai } \\
8 \text { ) } \times T \text {. } \\
\text { aestivum }(\text { Yannong } \\
\text { 19) }\end{array}$ & $\begin{array}{l}\text { RILs } \\
(229)\end{array}$ & 10 & $6.29-53.04$ & $\begin{array}{l}1 \mathrm{~A}, 1 \mathrm{~B}, 2 \mathrm{~A}, 2 \mathrm{D}, 3 \mathrm{~A} \\
4 \mathrm{~B}, 5 \mathrm{~A}, 5 \mathrm{D}, 6 \mathrm{~B}, 7 \mathrm{D}\end{array}$ & $\begin{array}{c}\text { Xgwm66.4-Xgwm234 (10.72), Xcfe254-Xmag972.1 (11.05), Xcau14.2- } \\
\text { ww160.1 (12.04), Xcfa2147-Xcwm109.1 (13.22), Xcfa2163.2-Xcwm216 } \\
\text { (53.04) }\end{array}$ & {$[73$} \\
\hline $\begin{array}{l}\text { Synthetic wheat } \\
(\mathrm{Am} 3) \times \text { Synthetic } \\
\text { wheat }(\text { Laizhou } 953)\end{array}$ & $\begin{array}{l}\text { BC5F2:F6 } \\
\text { families } \\
\quad(82)\end{array}$ & 9 & & $\begin{array}{c}1 \mathrm{~A}, 2 \mathrm{D}, 3 \mathrm{~A}, 4 \mathrm{~B}, 5 \mathrm{D} \\
6 \mathrm{~A}, 6 \mathrm{~B}, 6 \mathrm{D}, 7 \mathrm{~B}\end{array}$ & - & {$[74$} \\
\hline $\begin{array}{l}\text { T. aestivum }(\mathrm{BR} 34) \\
\quad \times \text { T. aestivum } \\
\quad \text { (Grandin) }\end{array}$ & $\begin{array}{l}\text { RILs } \\
\text { (118) }\end{array}$ & 1 & 16.3 & $5 \mathrm{BL}$ & Xbarc234.1-Xfcp273 (16.3) & {$[75$} \\
\hline $\begin{array}{l}\text { T. aestivum (Weimai } \\
8) \times \text { T. aestivum } \\
(\text { Luohan } 2)\end{array}$ & $\begin{array}{l}\text { RILs } \\
(302)\end{array}$ & 7 & $4.15-9.73$ & $\begin{array}{c}2 \mathrm{~A}, 3 \mathrm{~B}, 4 \mathrm{~A}, 5 \mathrm{~B}, 5 \mathrm{D} \\
6 \mathrm{~B}, 7 \mathrm{~A}\end{array}$ & - & {$[76$} \\
\hline $\begin{array}{l}\text { T. aestivum } \\
\text { (Xiaoyan 54) } \times T \text {. } \\
\text { aestivum }(\text { Jing } 411)\end{array}$ & $\begin{array}{l}\text { RILs } \\
(182)\end{array}$ & 5 & $1.14-9.25$ & $4 \mathrm{~B}, 4 \mathrm{D}, 5 \mathrm{~A}, 6 \mathrm{~A}$ & - & {$[77$} \\
\hline $\begin{array}{c}\text { T. aestivum } \\
\text { (CO940610) } \times T \text {. } \\
\text { aestivum }(\text { Platte }) \\
\text { T. aestivum }\end{array}$ & $\begin{array}{l}\text { DH lines } \\
(185)\end{array}$ & 5 & $5.6-12.3$ & $\begin{array}{l}\text { 5BS, 6AL, 6BS, } \\
\text { 7BS, 7DL }\end{array}$ & Xgwm540-Xgwm499 (12.3) & {$[78$} \\
\hline $\begin{array}{l}(\text { Choteau }) \times T \\
\text { aestivum } \\
\text { (Yellowstone) }\end{array}$ & RILs (97) & 2 & $17-19$ & $3 \mathrm{~B}, 5 \mathrm{~B}$ & Barc77 (17), Gwm499 (19) & {$[79$} \\
\hline T. aestivum & $\begin{array}{l}\text { DH lines } \\
\text { (68), RILs } \\
\text { (256), } \\
\text { RILs } \\
(182)\end{array}$ & 13 & $0.84-10.51$ & $\begin{array}{l}1 \mathrm{~B}, 1 \mathrm{D}, 2 \mathrm{~A}, 2 \mathrm{~B}, 2 \mathrm{D} \\
3 \mathrm{~B}, 4 \mathrm{~B}, 5 \mathrm{~B}, 6 \mathrm{D}, 7 \mathrm{~A}\end{array}$ & Xbarc353-Xbarc296 (10.51) & {$[80$} \\
\hline $\begin{array}{l}\text { T. aestivum } \\
\text { (Drysdale) } \times T \text {. } \\
\text { aestivum (gladius) }\end{array}$ & $\begin{array}{l}\text { RILs } \\
(155)\end{array}$ & 4 & & $2 \mathrm{~B}, 2 \mathrm{D}, 3 \mathrm{D}, 5 \mathrm{~A}$ & & {$[81]$} \\
\hline
\end{tabular}




\begin{tabular}{|c|c|c|c|c|c|c|}
\hline $\begin{array}{l}\text { T. aestivum }(\mathrm{CD} 87) \\
\times \text { T. aestivum } \\
\quad \text { (Katepwa) }\end{array}$ & $\begin{array}{l}\text { DH lines } \\
\quad(180)\end{array}$ & 12 & & $\begin{array}{l}1 \mathrm{D}, 2 \mathrm{~A}, 2 \mathrm{~B}, 2 \mathrm{D}, 4 \mathrm{~A} \\
4 \mathrm{~B}, 5 \mathrm{~A}, 5 \mathrm{~B}, 5 \mathrm{D}, 6 \mathrm{~A} \\
6 \mathrm{~B}, 6 \mathrm{D}, 7 \mathrm{~A}\end{array}$ & - & [82] \\
\hline $\begin{array}{l}\text { T. aestivum } \\
\text { (WCB414) } \times \text { T. } \\
\text { aestivum }(\mathrm{WCB} 617)\end{array}$ & $\begin{array}{l}\text { RILs } \\
(163)\end{array}$ & 11 & $4.7-16.5$ & $\begin{array}{l}1 \mathrm{~A}, 1 \mathrm{~B}, 2 \mathrm{~B}, 2 \mathrm{D}, 3 \mathrm{D} \\
\quad 4 \mathrm{~B}, 5 \mathrm{~B}, 6 \mathrm{~B}, 7 \mathrm{~B}\end{array}$ & $\begin{array}{l}\text { wPt0266-wPt9299 (10.4), wPt744808-wPt4368 (10.5), wPt1895-wPt6191 } \\
\text { (13.7), wPt1924-wPt7872 (16.5), wPt5234-wPt1437 (16.9) }\end{array}$ & [83] \\
\hline $\begin{array}{l}\text { T. aestivum } \\
\text { (Ning7840) } \times T \text {. } \\
\text { aestivum }(\text { Clark })\end{array}$ & $\begin{array}{l}\text { RILs } \\
(127)\end{array}$ & 4 & $11.5-22$ & 3A, 4BS, 5AL, 5BL & $\begin{array}{c}\text { IWA3069-IWA2023 (11.5), IWA197-IWA6713 (14.7), IWA4662- } \\
\text { IWA482 (20.1), IWA482-IWA1846 (20.5), IWA649-IWA7509 (21.5), } \\
\text { IWA482-IWA1846 (22) }\end{array}$ & [84] \\
\hline $\begin{array}{l}\text { T. aestivum } \\
\text { (RAC875) } \times T \text {. } \\
\text { aestivum (Kukri) }\end{array}$ & $\begin{array}{l}\text { DH lines } \\
(156)\end{array}$ & 18 & $7.00-17.00$ & $\begin{array}{l}1 \mathrm{~B}, 2 \mathrm{D}, 3 \mathrm{D}, 4 \mathrm{~B}, 5 \mathrm{~A} \\
5 \mathrm{~B}, 5 \mathrm{D}, 6 \mathrm{~A}, 7 \mathrm{~A}\end{array}$ & $\begin{array}{l}\text { wsnp_Ex_c38849_46284348 - stm0658acag(11), BS00021930_51- } \\
\text { RAC875_c35801_905 (11), wsnp_Ex_c2389_4479352-barc0353b (11), } \\
\text { Kukri_c42078_708- Kukri_c11106_292(12), Kukri_c60729_430- } \\
\text { Ra_c9427_300 (17), Ra_c9427_300- BobWhite_c34551_714 (17) }\end{array}$ & [85] \\
\hline $\begin{array}{l}\text { T. aestivum (Kitami } \\
81) \times \text { T. aestivum } \\
(\text { Kachikei } 63)\end{array}$ & $\begin{array}{l}\text { DH lines } \\
\quad(94)\end{array}$ & 1 & $28.5-32.1$ & $2 \mathrm{BS}$ & Xgpw3215 (28.5), Xwmc245 (29), Xgpw4382 (32.1)* & [86] \\
\hline $\begin{array}{l}\text { T. aestivum (Berkut) } \\
\quad \times \text { T. aestivum } \\
\text { (Krichauff) }\end{array}$ & $\begin{array}{c}\text { DH lines } \\
(138)\end{array}$ & 1 & 17.7 & $1 \mathrm{~A}$ & wpt9592-GBM1153 (17.7) & [87] \\
\hline $\begin{array}{l}\text { T. aestivum (Chuan } \\
35050) \times T \text {. } \\
\text { aestivum (Shannong } \\
483 \text { ) }\end{array}$ & $\begin{array}{l}\text { RILs } \\
(131)\end{array}$ & 11 & 4.1-32.7 & $\begin{array}{l}1 \mathrm{~A}, 1 \mathrm{D}, 2 \mathrm{~A}, 2 \mathrm{D}, 4 \mathrm{~A} \\
4 \mathrm{~B}, 5 \mathrm{D}, 7 \mathrm{D}\end{array}$ & $\begin{array}{c}\text { Xsrap21-Xwmc44 (11.6), Xswes340a-Xswes342a (11.7), Xgwm495- } \\
\text { Xwmc238 (19.5), Xwmc308-Xsrap7c (25.8-27.1), Xgdm67-Xgwm428 } \\
\text { (32.7) }\end{array}$ & [88] \\
\hline $\begin{array}{l}\text { T. turgidum (Duilio) } \\
\times \text { T. turgidum } \\
\quad \text { (Avonlea) }\end{array}$ & $\begin{array}{l}\text { RILs } \\
(134)\end{array}$ & 8 & $10.00-14.00$ & $\begin{array}{l}1 \mathrm{~B}, 2 \mathrm{~B}, 3 \mathrm{~B}, 4 \mathrm{~A}, 5 \mathrm{~A} \\
7 \mathrm{~A}, 7 \mathrm{~B}\end{array}$ & IWB71842 (12), IWB71180 (12), IWB71499 (12), IWB28350 (14) & [89] \\
\hline $\begin{array}{l}\text { T. aestivum } \\
\text { CO940610 } \times T \text {. } \\
\text { aestivum (Platte) }\end{array}$ & $\begin{array}{l}\mathrm{BC} 3 \mathrm{~F} 2: 3 \\
\text { population } \\
(35)\end{array}$ & 4 & $13.2-19.2$ & $1 \mathrm{~B}, 6 \mathrm{~B}, 7 \mathrm{~B}$ & Bx7-MAR (13.2), Xwmc182a (17.7), Xwmc182b (19.2) & [90] \\
\hline
\end{tabular}




\subsection{Epistatic Interactions for Grain Protein Content}

Development of efficient statistical and genomic tools have allowed the geneticists to identify and map the QTLs involved in epistatic interactions for GPC [56, 63, 69, 70, 77]. Softwares like QTLMapper [91], QTLNetwork [92], and IciMapping [93] were frequently used to locate the epistatic QTLs. Kulwal et al. [56] identified four QTLs which were involved in two digenic QQ epistatic interactions in one RIL population and six E-QTLs involved in three digenic QQ epistatic interaction in other RIL population in bread wheat. However, these interactions accounted for only $2.68 \%$ and $6.04 \%$ of phenotypic variation in first and second population respectively. Patil et al. [63] identified one pair of epistatic interaction using a RIL population derived from a durum wheat cross between PDW 233 and Bhalegaon 4. Zhao et al., [69] identified two digenic epistatic interaction for GPC, both involving only E-QTL using a population developed from two Chinese wheat cultivars. Conti et al., [70] identified five pairs of epistatic interactions for GPC, in addition to one QQE interaction using RIL population obtained from the cross between the UC Davis wheat breeding line UC1113 and the variety Kofa. In another study, Xu et al. [77] identified two significant digenic interaction involving four M-QTL for GPC using a RIL population developed from the Chinese cultivars.

Among all the QTLs identified for GPC, the most critical QTL identified so far is Gpc-B1. This QTL was first detected in a wild accession (FA-15-3) of tetraploid wheat, Triticum turgidum var. dicoccoides [94]. Later on, the same accession was used to produce a complete set of chromosome substitution lines, in the background of modern durum wheat [95]. Using substitution lines, Gpc-B1 gene was later mapped on chromosome arm 6BS which explained $66 \%$ of the phenotypic variation for GPC [96]. Gpc-B1 was cloned using map-based cloning approach, and it was found that Gpc-B1 encodes a NAC transcription factor (NAM-B1) that accelerates senescence and also affects grain protein, zinc, and iron content in wheat [97]. Introgression material with functional GPC-B1 allele into the background of elite, varieties is released in different countries [98].

\section{Biofortification for Grain Fe and Zn Content}

Using agronomical methods, the $\mathrm{Zn}$ content of grain can be increased by fertilising the plants with zinc fertilizers. For example, Zhang et al., [99], reported a 58\% increase in whole grain $\mathrm{Zn}, 76 \%$ increase in wheat flour $\mathrm{Zn}$ using a foliar application of $0.4 \% \mathrm{ZnSO} \cdot 7 \mathrm{H} 2 \mathrm{O}$. In another study, Zou et al., [100] increased grain $\mathrm{Zn}$ by $84 \%$ and $90 \%$, by using $\mathrm{Zn}$ as a foliar spray. However, in case of iron, these agronomic approaches have been less effective [101], except if combined with increased nitrogen fertilizers [102] which may not be economically acceptable. At CIMMYT, Mexico (International Maize and Wheat Improvement Center), conventional breeding has been successfully used to increase the zinc content of wheat grains [103]. To date, four Zn biofortified varieties have been released - 'Zinc Shakti' (in the background of Indian variety PBW343), 'Zincol 2016' (in the background of Pakistani variety NARC2011) and 'WB02' and 'HPBW-01' having 14, 9, 7 and 7 PPM zinc in their grains, respectively [103]. These four varieties developed in collaboration with CIMMYT, are currently being grown in India and Pakistan. Furthermore, human intervention trials to examine the effectiveness of consuming flour made from $\mathrm{Zn}$ biofortified wheat are presently being carried out in Pakistan [104]. Although success in Zn biofortification has been achieved, no Fe biofortified variety could be produced so far using conventional breeding.

\subsection{QTLs for grain Fe and Zn concentration in Wheat}

Marker-assisted breeding can be a potential breeding strategy to develop the Fe and $\mathrm{Zn}$ biofortified ears of wheat. The knowledge of the genetic basis for $\mathrm{Fe}$ and $\mathrm{Zn}$ concentrations are required for successful employment of marker-assisted selection. Various QTL mapping studies have allowed the identification of many QTLs for both Fe and Zn (Table 2). Unfortunately, Most of the QTLs identified for Zn and Fe, were not stable across the studied environments. Shi et al. [105] detected four and seven QTLs for Zn concentration and $\mathrm{Zn}$ content, respectively. They suggested a possibility to improve both grain Zn concentration and content simultaneously because all the four QTLs for Zn concentration were co-located with the QTLs for Zn content. QTLs for Zn concentration on chromosomes $4 \mathrm{~A}$ and $4 \mathrm{D}$ and, four QTLs for grain Zn content on chromosome 2D, 3A and 4A were co-located with the QTLs for P contents, indicating a possibility of improving grain $\mathrm{Zn}$ and $\mathrm{P}$ density simultaneously in wheat.

QTLs for grain zinc and iron have also been mapped in populations derived from crosses between T. boeoticum and T. monococcum [106], durum wheat and wild emmer [64] synthetic hexaploid wheat and T. spelta [107, 108, 109]. Tiwari et al. [106] mapped 2 QTL for grain Fe on chromosomes 2A and 7A explaining 
12.6 and $11.7 \%$ of phenotypic variation and 1 QTL for grain Zn on chromosome 7A explaining $18.8 \%$ of total phenotypic variation, using a RIL population derived from a cross between T. boeoticum accession 'pau5088' and T. monococcum accession 'pau14087'. Recently in 2017, Crespo-Herrera et al. [108] identified several significant QTLs with a region named as nQGZn.cimmyt-7B_1P2 on chromosome 7B explaining the largest proportion $(32.7 \%)$ of total phenotypic variance for GZn and one QTL on chromosome 4A (QGFe.cimmyt4A_P2), explaining the largest (21.14\%) proportion of phenotypic variance of the GFe in two RIL populations derived from T. spelta L. and synthetic hexaploid wheat crosses. In other study, Krishnappa et al. [109] mapped four QTLs, explaining $20 \%$ of total phenotypic variation and five QTLs, explaining 32\% of total phenotypic variation for GFe and GZn, respectively using a RIL population derived from a cross between an Indian wheat variety 'WH542' and a synthetic derivative. Further, they identified an association between GFe, GZn and GPC and, a region in the interval of Xgwm359-Xwmc407 on chromosome 2A. QTLs for GZn and GFe co-localized on chromosome 5A (Xgwm126- Xgwm595) and 7A (Xbarc49-Xwmc525). Furthermore, Xu et al., [77] also clearly indicated the role of epistasis in the expression of these traits in wheat grains. One QTL located on chromosome 2A (Xgwm501-Xgwm156.2) showed additive ×additive epistatic interaction with the other QTL (Xwmc181-Xcfd267.1) located on the same chromosome 2A for GZn concentration, and one QTL on chromosome 2B (Xbarc1138.2-Xcfd238) showed same additivexadditive epistatic interaction with the other QTL (Xgwm617-Xcfa2114) located on the chromosome 6A for GFe.

Several studies have identified and mapped QTLs for high GFe and GZn concentrations on different chromosomes 1A, 1B, 1D, 2A, 2B, 3A, 3B, 3D, 4A, 4B, 4D,5A, 5B, 5D, 6A, 6B, 7A, 7B and 7D found in different diploid, tetraploid and hexaploid wheat species (Table 2). Among these studies, some have reported a significant positive correlation between GZn and GFe across different environments indicating co-localization of QTL or pleiotropic effect regulating the concentrations of both GZn and GFe in wheat (Table 2). For instance, Tiwari et al. [106] showed the colocalization of QTLs for GZn and GFe on chromosome 7A between the flanking markers Xcfd31-Xcfa2049, and closest markers viz. wPt-9555 and Xcfa2019 were also mapped on 7A chromosome indicating the association with both GZn and GFe [64, 109]. Colocalization of QTLs for GZn and GFe on other chromosomes such as 2A [109], 2B [87], 4BS [110], 5A [77, 109] and 6B [111]. This colocalization of QTLs provides the opportunity to employ only one MAS programme to elevate the concentrations of both GZn and GFe, simultaneously. 
Table 2. List of quantitative trait loci (QTL) identified for grain zinc (GZn), grain iron (GFe) and grain selenium (Se) content.

\begin{tabular}{|c|c|c|c|c|c|c|}
\hline Cross & $\begin{array}{l}\text { Populatio } \\
\text { n type } \\
\text { and size }\end{array}$ & $\begin{array}{l}\text { No. of } \\
\text { total } \\
\text { QTLs }\end{array}$ & $\begin{array}{l}\text { PVE } \\
\text { range }\end{array}$ & $\begin{array}{l}\text { Chromosome } \\
\text { s }\end{array}$ & Marker intervals / nearest markers for major QTL (PVE) & References \\
\hline $\begin{array}{l}\text { T. aestivum Hanxuan } 10 \times T \text {. } \\
\text { aestivum Lumai } 14\end{array}$ & DH (119) & $\begin{array}{l}\text { Zinc conc.- } \\
4 \text { and } \mathrm{Zn} \\
\text { content-7 }\end{array}$ & $\begin{array}{l}5.3-11.9 \\
4.6-14.6\end{array}$ & $\begin{array}{l}1 \mathrm{~A}, 2 \mathrm{D}, 3 \mathrm{~A} \\
4 \mathrm{~A}, 4 \mathrm{D}, 5 \mathrm{~A} \\
\quad 7 \mathrm{~A}\end{array}$ & $\begin{array}{c}\text { Xgwm192-WMC331 (11.9); Xgwm291-Xgwm410 (10.69) } \\
\text { [Zn conc.]; P3470.3-P3176.1 (13.4); WMC488-P2071-180 } \\
\text { (14.6) [Zn content] }\end{array}$ & [105] \\
\hline $\begin{array}{l}\text { T. aestivum }(\mathrm{RAC} 875-2) \times T \text {. } \\
\text { aestivum (cascades) }\end{array}$ & DH (90) & $\begin{array}{l}\text { GZn-4; } \\
\text { GFe-1 }\end{array}$ & & $\begin{array}{l}3 \mathrm{D}, 4 \mathrm{~B}, 6 \mathrm{~B} \\
\quad 7 \mathrm{~A} ; 3 \mathrm{D}\end{array}$ & & [112] \\
\hline $\begin{array}{l}\text { T. boeoticum }(\mathrm{Tb} 5088) \times T \text {. } \\
\text { monococcum }(\mathrm{Tm} 14087)\end{array}$ & RIL (93) & $\begin{array}{l}\text { GZn-2; } \\
\text { GFe-3 }\end{array}$ & $\begin{array}{l}7.0-12.6 \\
9.0-18.8\end{array}$ & $7 \mathrm{~A} ; 2 \mathrm{~A}, 7 \mathrm{~A}$ & $\begin{array}{c}\text { Xcfd31-Xcfa2049 (18.8) [GZn]; Xwmc382-Xbarc124 (12.6); } \\
\text { Xgwm473-Xbarc29 (11.7) [GFe] }\end{array}$ & [106] \\
\hline $\begin{array}{l}\text { Durum wheat (cv. Langdon) and } \\
\text { wild emmer (accession G18-16) }\end{array}$ & RIL (152) & $\begin{array}{l}\text { GZn-6; } \\
\text { GFe-11 }\end{array}$ & $\begin{array}{l}1.3-23.5 \\
0.8-17.8\end{array}$ & $\begin{array}{l}2 \mathrm{~A}, 5 \mathrm{~A}, 6 \mathrm{~B} \\
7 \mathrm{~A}, 7 \mathrm{~B} ; 2 \mathrm{~A} \\
2 \mathrm{~B}, 3 \mathrm{~A}, 3 \mathrm{~B} \\
4 \mathrm{~B}, 5 \mathrm{~A}, 6 \mathrm{~A} \\
6 \mathrm{~B}, 7 \mathrm{~A}, 7 \mathrm{~B}\end{array}$ & $\begin{array}{c}\text { wPt8216 (15.4), wPt } 9555 \text { (15.7), gwm445 (15.4) [GZn]; } \\
\text { gwm154 (14.6), wpt-9555 (10.7), gwm473 (11.7); gwm1054 } \\
\text { (11.7) [GFe] }\end{array}$ & [64] \\
\hline $\begin{array}{l}\text { T. aestivum (Xiaoyan } 54) \times T \text {. } \\
\text { aestivum (Jing 411) }\end{array}$ & RIL (182) & $\begin{array}{l}\text { GZn-2; } \\
\text { GFe-2 }\end{array}$ & $\begin{array}{l}4.23-6.88 \\
3.27-3.43\end{array}$ & $4 \mathrm{~B}, 5 \mathrm{~A} ; 5 \mathrm{~A}$ & & [77] \\
\hline $\begin{array}{l}\text { T. aestivum (Hanxuan 10) } \times T \text {. } \\
\text { aestivum (Lumai 14) }\end{array}$ & DH (120) & GFe-4 & $6.1-14.6$ & $\begin{array}{l}4 \mathrm{D}, 5 \mathrm{~A}, 7 \mathrm{~A}, \\
7 \mathrm{~B}\end{array}$ & WMC74-Xgwm291 (14.6) & [113] \\
\hline $\begin{array}{l}\text { T. aestivum (Tabassi) } \times T \text {. } \\
\text { aestivum (Taifun) }\end{array}$ & RIL (118) & $\begin{array}{l}\text { GZn-2; } \\
\text { GFe-6 }\end{array}$ & $\begin{array}{l}40.22- \\
50.79 \\
8.94-47\end{array}$ & $\begin{array}{l}1 \mathrm{~A}, 4 \mathrm{~A} ; 2 \mathrm{~A} \\
3 \mathrm{D}, 4 \mathrm{D}, 7 \mathrm{~B} \\
\quad 7 \mathrm{D}\end{array}$ & $\begin{array}{c}\text { Xgwm4026-Xgwm1081 (40.22), Xgwm3094-Xgwm164 (50.79) } \\
\text { [GZn]; Xgwm312-Xgwm817 (12.58), Xgwm817-Xgwm630 } \\
\text { (17.04), Xgwm4670-Xgwm194 (44.60), Xgwm1047-Xgwm383 } \\
\text { (44.71), Xgwm767-Xgwm3036 (10.92) }\end{array}$ & [114] \\
\hline $\begin{array}{l}\text { T. aestivum (PBW343) } \times T \text {. } \\
\text { aestivum (Kenya Swara) }\end{array}$ & RIL (177) & GZn-3 & $\begin{array}{c}10.00- \\
15.00\end{array}$ & $1 \mathrm{~B}, 2 \mathrm{~B}, 3 \mathrm{~A}$ & wPt-6174 (10), wPt-3103 (11), wPt-0286 (15) & [115] \\
\hline $\begin{array}{l}\text { Synthetic hexaploid (SHW-L1) } \times \\
\text { T. aestivum (Chuanmai 32) }\end{array}$ & RIL (171) & $\begin{array}{l}\text { GZn-4; } \\
\text { GFe-4 }\end{array}$ & $\begin{array}{l}5.5-8.6 \\
5.4-9.5\end{array}$ & $\begin{array}{l}2 \mathrm{D}, 3 \mathrm{D}, 4 \mathrm{D} \\
5 \mathrm{D} ; 2 \mathrm{~B}, 5 \mathrm{~B} \\
5 \mathrm{D}, 7 \mathrm{D}\end{array}$ & & [107] \\
\hline $\begin{array}{l}\text { T. aestivum (Chuanmai } 42) \times T \text {. } \\
\text { aestivum (Chuannong 16) }\end{array}$ & RIL (127) & $\begin{array}{l}\text { GZn-3; } \\
\text { GFe-4 }\end{array}$ & $\begin{array}{c}13.8-15.9 \\
9.2-19.1\end{array}$ & $\begin{array}{l}3 \mathrm{D}, 4 \mathrm{D}, 5 \mathrm{~B} \\
4 \mathrm{~A}, 4 \mathrm{D}, 5 \mathrm{~A} \\
\quad 5 \mathrm{~B}\end{array}$ & $\begin{array}{c}\text { Xgwm213-Xbarc216 (13.8), Xbarc6-Xcfe172 (14.5), Xcfa2149- } \\
\text { Xbarc48 (15.9) [GZn]; Xwmc468-Xbarc170 (10.3), Xsrap97- } \\
\text { Xbarc330 (10.4), Xgwm154-Xbarc108 (19.1) }\end{array}$ & [107] \\
\hline $\begin{array}{l}\text { T. spelta }(\mathrm{PI} 348449) \times T \text {. } \\
\text { aestivum }(\mathrm{HUW} 234)\end{array}$ & RIL (185) & $\begin{array}{l}\text { GZn-5; } \\
\text { GFe-5 }\end{array}$ & $\begin{array}{l}4.25- \\
16.46 ; 5.6- \\
25.95\end{array}$ & $\begin{array}{l}2 \mathrm{~A}, 2 \mathrm{~B}, 3 \mathrm{D} \\
6 \mathrm{~A}, 6 \mathrm{~B} ; 1 \mathrm{~A} \\
2 \mathrm{~A}, 3 \mathrm{~B}\end{array}$ & $\begin{array}{c}\text { 989092|F|0-1101425|F|0 (16.46) [GZn]; 1708014|F|0-1000008|F|0 } \\
\text { (16.55), 3022954|F|0-1102324|F|0 (25.95) [GFe] }\end{array}$ & [116] \\
\hline
\end{tabular}




\begin{tabular}{|c|c|c|c|c|c|c|}
\hline $\begin{array}{l}\text { T. aestivum (Berkut) } \times T \text {. } \\
\text { aestivum (Krichauff) }\end{array}$ & DH (138) & $\begin{array}{l}\text { GZn-2; } \\
\text { GFe-1 }\end{array}$ & $\begin{array}{l}23.1-35.9 \\
22.2\end{array}$ & $1 \mathrm{~B}, 2 \mathrm{~B} ; 2 \mathrm{~B}$ & $\begin{array}{l}\text { wmc036c-cfa2129 (23.1), gwm120-wpt2430 (35.9) [GZn]; } \\
\text { gwm120-wpt2430 (22.2) [GFe] }\end{array}$ & [87] \\
\hline $\begin{array}{c}\text { T. aestivum }(\text { SeriM82) } \times T \text {. } \\
\text { dicoccoides } / \text { Ae. Tauschii }(\mathrm{SHW} \\
\text { CWI76364) }\end{array}$ & RIL (140) & $\begin{array}{l}\text { GZn-3; } \\
\text { GFe-5 }\end{array}$ & $\begin{array}{l}8.3-17.3 ; \\
7.5-14.5\end{array}$ & $\begin{array}{l}\text { 4BS, 6AL, } \\
6 \mathrm{BL} ; 2 \mathrm{BL} \\
\text { 2DS, 4BS, } \\
6 \mathrm{AL}, 7 \mathrm{DS}\end{array}$ & $\begin{array}{l}\text { TP91631-TP81797 (17.3)[GZn]; TP91631-TP81797 (10.7), } \\
\text { TP43715-TP37547 (14.5) [GFe] }\end{array}$ & [110] \\
\hline $\begin{array}{l}\text { T.aestivum }(\text { Adana99) } \times T \text {. } \\
\text { sphaerococum }(70711)\end{array}$ & RIL (127) & $\begin{array}{l}\text { GZn-10; } \\
\text { GFe-7 }\end{array}$ & $9-31 ; 9-18$ & $\begin{array}{l}\text { 1B, 1D, 2B, } \\
3 \mathrm{~A}, 3 \mathrm{D}, 6 \mathrm{~A} \\
6 \mathrm{~B}, 7 \mathrm{~A}, 7 \mathrm{~B} \\
1 \mathrm{~B}, 2 \mathrm{~A}, 2 \mathrm{~B} \\
3 \mathrm{~A}, 6 \mathrm{~B}, 7 \mathrm{~B}\end{array}$ & $\begin{array}{c}\text { rPt-6561 (12), wPt-2698-wPt-0398 (14), wPt-2083-wPt-6083 } \\
\text { (15), wPt-733,112 (25), wPt-7161-wPt-9812 (31) [GZn]; wPt- } \\
\text { 667,798-wPt-7065 (14), wPt-1394-wPt-7864 (17), wPt-5922 (18) } \\
\text { [GFe] }\end{array}$ & [111] \\
\hline $\begin{array}{l}\text { T. spelta }(\text { Bubo }) \times \text { resynthesized } \\
\text { hexaploid wheat (Turtur) }\end{array}$ & RIL (188) & $\begin{array}{l}\text { GZn-4; } \\
\text { GFe-3 }\end{array}$ & $\begin{array}{c}2.86- \\
16.75 \\
5.49-10.35\end{array}$ & $\begin{array}{l}1 \mathrm{~B}, 6 \mathrm{~A}, 7 \mathrm{~B} \\
3 \mathrm{~A}, 4 \mathrm{~B}, 5 \mathrm{~B}\end{array}$ & $\begin{array}{c}\text { 3934172-3934936 (15.10), 3945822-1132640F0-5CG (16.75) } \\
\text { [GZn]; } 1234521 ; 3034169 \mathrm{~F} 0-11 \mathrm{AG}(10.35) \text { [GFe] }\end{array}$ & [108] \\
\hline $\begin{array}{l}\text { Synthetic hexaploid wheat } \\
\text { (Louries) } \times \text { T. spelta(Bateleur) }\end{array}$ & RIL (188) & $\begin{array}{l}\text { GZn-12; } \\
\text { GFe-7 }\end{array}$ & $\begin{array}{c}3.30- \\
32.79 \\
5.79-21.14\end{array}$ & $\begin{array}{l}1 \mathrm{~A}, 1 \mathrm{~B}, 3 \mathrm{~B} \\
3 \mathrm{D}, 4 \mathrm{~A}, 5 \mathrm{~B} \\
6 \mathrm{~A}, 7 \mathrm{~B}, 7 \mathrm{D} \\
2 \mathrm{~A}, 2 \mathrm{~B}, 3 \mathrm{~B} \\
4 \mathrm{~A}, 4 \mathrm{D}, 5 \mathrm{~B}\end{array}$ & $\begin{array}{c}4543935-3937719(10.78), 4991478-3937490(11.25), 4394657- \\
3947677 \text { (10.93), } 1079651 ; 1262636(32.79)[\mathrm{GZn}] ; \text { 4 } 407677- \\
1129284 \text { (11.62), 4262668-1226245(14.23), 2363822-3961236 } \\
\text { (14.62), 3385350-1211533 (21.14) [GFe] }\end{array}$ & [108] \\
\hline $\begin{array}{l}\text { T. aestivum }(\text { WH542) } \times \text { synthetic } \\
\text { derivative }(\text { Triticum dicoccon } \\
\text { PI94624/Aegilops sqarrosa } \\
[409] / / \mathrm{BCN})\end{array}$ & RIL (286) & $\begin{array}{l}\text { GZn-5; } \\
\text { GFe-4 }\end{array}$ & $\begin{array}{c}3.2-14.4 ; \\
2.3-6.8\end{array}$ & $\begin{array}{l}\text { 2A, 4A, 5A, } \\
7 \mathrm{~A}, 7 \mathrm{~B} ; 2 \mathrm{~A}, \\
5 \mathrm{~A}, 7 \mathrm{~A}, 7 \mathrm{~B}\end{array}$ & & [109] \\
\hline $\begin{array}{l}\text { T. aestivum (SHW-L1) } \times T \text {. } \\
\text { aestivum (Chuanmai } 32)\end{array}$ & RILs (171) & 4 & $6.4-28.5$ & $\begin{array}{l}\text { Selenium } \\
\text { 3D, 4A, 5B, } \\
\text { 7D }\end{array}$ & $\begin{array}{c}\text { wPt-5120-wPt-0708 (10.1), wPt-6191-wPt-8658 (23.4), wPt- } \\
\text { 671684-wPt-667506 (28.5) }\end{array}$ & [107] \\
\hline $\begin{array}{l}\text { T. aestivum (Chuanmai } 42) \times T \text {. } \\
\text { aestivum (Chuannong 16) }\end{array}$ & RILs (127) & 1 & 35.1 & $4 \mathrm{D}$ & Xbarc241-Xsrap15a (35.1) & [107] \\
\hline $\begin{array}{l}\text { T. aestivum }(\mathrm{TN18}) \times \text { T. aestivum } \\
\text { (LM6) }\end{array}$ & RILs (184) & 7 & $7.44-15.57$ & $2 \mathrm{~B}, 5 \mathrm{~B}$ & $\begin{array}{c}\text { S-1120640ĐD-3024250 (10.42), D-3022447ĐS-1020653 (11.75), } \\
\text { D-3956657ĐS-1105975 (12.56), RAC875-c33387_888ĐD- } \\
3936732 \text { (13.93), D-3022447ĐS-1020653 (14.36), S- } \\
\text { 3064451ĐD-1238798 (15.57), }\end{array}$ & [117] \\
\hline $\begin{array}{l}\text { Synthetic wheat (SHW-L1) } \times T \text {. } \\
\text { aestivum (Chuanmai32) }\end{array}$ & RILs(171) & 24 & $4.38-28.38$ & $\begin{array}{c}1 \mathrm{~B}, 3 \mathrm{D}, 5 \mathrm{~A} \\
6 \mathrm{~A}, 6 \mathrm{~B}, 6 \mathrm{D} \\
7 \mathrm{D}\end{array}$ & $\begin{array}{c}\text { wPt-3566 wPt-8168 (11.58), wPt-667,315 wPt-741,543 (14.34), } \\
\text { wPt-7273 wPt-9792 (15.64), wPt-733,447 wPt-667,315 (21.15), } \\
\text { wPt-741,599 wPt-742,156 (25.57), wPt-733,447 wPt-667,315 } \\
\text { (25.58), wPt-733,447 wPt-667,315 (28.38), }\end{array}$ & [118] \\
\hline
\end{tabular}




\subsection{Breeding strategies to develop Zn and Fe biofortified wheat}

Conventional breeding methods have been successfully employed at various research institute in collaboration with CIMMYT to biofortify the wheat grains with Zn [103, 104]. But, Fe content in wheat grain could not be increased using these methods. For instance, several QTL mapping studies have been conducted and so many QTLs for GFe and GZn, have been mapped on different chromosomes of wheat. So, now, efforts can be made to utilize the QTL information in marker-assisted backcrossing schemes to produce Zn and Fe biofortified wheat. Co-localization of QTLs for GFe and GZn may further provide the opportunity to target them for improving the concentration of both in wheat grains, simultaneously [109]. Moreover, in various QTL studies, some QTLs for these GFe and GZn are also co-localized with those of phosphorus [64, 105], selenium [107], calcium, manganese and magnesium [64] or other agronomically essential traits including grain protein content [77] and thousand grain weight [110].

The genetic variation available for breeders is not limited. For instance, Gorafi et al. [120] assessed 47 synthetic wheat lines derived from crosses between tetraploid wheat cultivar 'Langdon' and 47 Ae. tauschii lines collected from different geographical Areas. Grain Fe and Zn ranged fromfrom 22.2 to $78.5(\mathrm{mg} / \mathrm{kg}$ ) and 20.6 to $65.8(\mathrm{mg} / \mathrm{kg})$, respectively in these synthetic wheat lines, which can be utilized as potential genetic resources for breeding wheat cultivars with high mineral content. In 2017, Magallanes-López et al. [121], reported a range from 25.7 to $40.5 \mathrm{mg} / \mathrm{kg}$ and from 24.8 to $48.8 \mathrm{mg} / \mathrm{kg}$ for zinc and iron, respectively, in 46 durum varieties. In a recent study conducted in Iran, Amiri et al. [122] assessed five elite lines and 75 historical and modern cultivars (released or introduced from 1942 to 2012), and reported a wide range with a mean of $72.30 \pm 0.69(\mathrm{mg} / \mathrm{kg}), 39.54 \pm 0.51(\mathrm{mg} / \mathrm{kg}), 528.92 \pm 11.0(\mathrm{~g} / \mathrm{ha})$ and $282.66 \pm 5.7(\mathrm{~g} / \mathrm{ha})$ for GFeC, GZnC, GFeY and GZnY, respectively. They grouped all assessed materials in two clusters, older genotypes and landraces with high $\mathrm{GFeC}, \mathrm{GZnC}$ were kept in one group and remaining with low $\mathrm{GFeC}, \mathrm{GZnC}$ were kept in other, these can be utilized as parents in crossing programs.

\section{Biofortification for grain selenium content}

Selenium (Se), an essential mineral element, incorporates into proteins to make seleno-proteins, which plays a critical role in human health. These seleno-proteins are necessary antioxidant enzymes that prevent cellular damage from free radicals resulting in the prevention of chronic diseases, such as cancer and heart

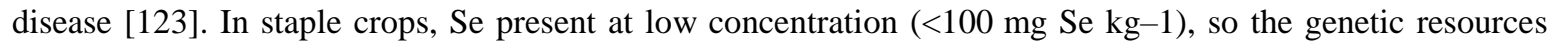
having high amount of Se, as well as the genes/QTLs controlling Se concentration are need to be identified to bred the Se-rich varieties either using conventional or molecular breeding approach such as MAS [118].

There are contrary reports for the amount of genetic variability among wheat cultivars for Se density in grain. Some studies have found no evidence for genetic variability [124, 125], while another found higher Se density in wheat grains [126]. The Se-density in wheat grain was about $16 \mu \mathrm{g} \mathrm{kg}^{-1}$ which is insufficient to meet the Se requirement for human [125]. In 2005, Lyons et al. [127], surveyed 665 ancestral and wild relatives of wheat, wheat landrace accessions, populations, and commercial cultivars grown in Mexico and Australia for Se concentration in grain. They found grain Se concentrations in the range of 5-720 $\mu \mathrm{gkg}^{-1}$, but unfortunately, much of this variation was correlated with spatial variation in soil selenium and, no significant genotypic variation in grain Se density was observed. Although, $42 \%$ and 35\% higher grain Se concentration was found in Aegilops tauschii and rye, respectively. On the other hand, Piergiovanni et al. in 1997 [126], found significant differences between emmer (T. dicoccon Schrank) and spelt (T. spelta L.) accessions, and wheat cultivars for higher contents of Se, $\mathrm{Li}, \mathrm{Mg}, \mathrm{P}$ and $\mathrm{Zn}$. They reported a range of 1.9-5.8 $\mu \mathrm{g} / 100 \mathrm{~g}$ with a mean of $3.9 \mu \mathrm{g} / 100 \mathrm{~g}$ and $1.8-3.5 \mu \mathrm{g} / 100 \mathrm{~g}$ with a mean of $2.8 \mu \mathrm{g} / 100 \mathrm{~g}$ in spelt and emmer accessions.

\subsection{QTLs for Se Content in Wheat Grain}

Knowledge of the underlying genetic mechanism of Se content is the necessary step for Se biofortification of wheat to enhance grain Se content. QTL mapping helps in understanding the genetic basis but, unfortunately, only a small number of QTL mapping studies have been conducted for mapping the QTLs for Se concentration in wheat grain [107, 117, 118, 119]. In 2014, Pu et al. [107] identified a total of 39 QTLs for five micronutrients ( $\mathrm{Se}, \mathrm{Fe}, \mathrm{Zn}, \mathrm{Cu}$ and $\mathrm{Mn}$ ) concentrations using two RIL population derived from the crosses between SHW-L1 (synthetic hexaploid wheat) and Chuanmai 32 and, Chuanmai 42 and Chuannong 16 respectively. In the first population, they mapped four QTLs on chromosomes 3D, 4A, 5B, 7D explaining 6.4-28.5\% of the genetic variance, while in the second population, they mapped only one QTL on chromosome $4 \mathrm{D}$ revealing $35.1 \%$ of 
genetic variance for Se concentration in wheat grain. Wang et al. [117], mapped 16 QTLs (seven at the seedling stage and nine at the adult stage) for six Se content-related traits on eight chromosomes, 1B, 2B, 4B, 5A, 5B, 5D, 6A, and 7D using a RIL population derived from a cross between two Chinese winter wheat varieties (Tainong18 and Linmai6) under both field-grown and hydroponic conditions. Each mapped QTL explained from 7.37 to $20.22 \%$ of the total phenotypic variance of Se content. Recently in 2018 , for the first time, Pu et al. [118] documented a Se rich synthetic wheat line and mapped a total of 24 QTLs for Se component traits on chromosomes 1B, 3D, 5A, 6A, 6B, 6D and 7D. Notably, a QTL located on chromosome 3D (marker interval 214.00-218.00, Qse.sau-3D), was explaining the maximum amount (up to 28.38\%) of genetic variation.

In another study, Yan et al. [119] mapped a total of 15 QTLs on chromosomes 1A, 1B, 2B, 3A, 4B, 5A, 6A, 7A, 7B explaining $1.4 \%$ to $18.6 \%$ of the phenotypic variation for GSeC (grain Se conc.) and GSeY (grain Se yield) using a RIL population derived from a cross between T. dicoccoides (accession G18-16) and Langdon (Durum wheat). These above findings provide various main effect QTLs and their linked markers, which can be utilized in the MAS program for Se biofortification of wheat grain. QTLs regulating selenium concentration in wheat grains have been mapped on chromosomes $1 \mathrm{~A}, 1 \mathrm{~B}, 2 \mathrm{~B}, 3 \mathrm{~A}, 3 \mathrm{D}, 5 \mathrm{~A}, 5 \mathrm{~B}$ and homeologous groups of 4 and 6 chromosomes (Table 2). Pu et al. [107] identified a QTL on chromosome 4D which explained $35.1 \%$ of total phenotypic variance in common wheat. Markers associated with identified QTLs have been given in Table 2.

\section{Biofortification for the Grain Yellow Pigment Content (GYPC)}

GYPC is responsible for yellowness of wheat flour which is regarded better for human health because of antioxidant properties of carotenoids involved in this pigmentation. The yellow pigment in the wheat grain is predominantly associated with carotenoid compounds (carotenes and xanthophyll) which affect the quality and nutritional value of wheat grain products [128].

\subsection{QTLs Identified for GYPC in Wheat}

Since GYPC is a complex quantitative trait, several efforts have been made to identify the genetic regions associated with the trait. To our knowledge, in last two decades, several QTL mapping studies (mostly in durum wheat crosses) have been conducted to map more than eighty QTLs associated with GYPC in wheat (Table 3). Interestingly, in each mapping studies, at-least one QTL has been mapped on chromosome 7 of both T. turgidum L. var durum and T. aestivum explaining a significant part of phenotypic variation [129, 130, 131, 132, 133, 134, 135, 136, 137, 138, 139, 140, 141]. Parker et al. [129] identified two regions on chromosomes 3A and 7A, explaining, $13 \%$ and $60 \%$ of the genetic variation respectively. They further fine mapped the region on chromosome 7A and identified seven additional AFLP markers within the target region. RIL population of a cross between T. turgidum L. var. durum cultivar and T. dicoccoides (acc.600545), Elouafi et al. [130] mapped three QTLs on the chromosomal group 7 (one on 7AL and two on 7BL telomeres) explaining 62\% of the total phenotypic variation. All three QTLS were consistent and showed a strong genetic effect and a weak QTL $\times$ E effect. Pozniak et al. [131] located phytoene synthase 1 (Psyl) and phytoene synthase 1 (Psy2) genes to the group 7 and 5 chromosomes, respectively. They also identified four QTLs underlying phenotypic variation in endosperm colour on chromosomes 2A, 4B, 6B, and 7B. Psyl-1 allelic locus of Psy gene co-segregated with the 7B QTL, demonstrating the role of this gene for endosperm colour. This became the first report of mapping Psy genes and supporting the role of Psyl-1 in increased levels of endosperm colour in durum wheat. In another study, Zhang et al. [134] also mapped $P s y-A 1$ gene on chromosome 7A with PVE value $33.9 \%$ and interestingly also detected a QTL region on 1RS (1B.1R translocation) explaining 31.9\% of the phenotypic variance.

In 2008, Patil et al. [132] identified four different stable QTLs on chromosome 1A, 3B, 5B, 7B explaining $5-8.75 \%$ of phenotypic variation and one most robust QTL on the distal part of chromosome 7AL explaining $55.22 \%$ of the variation in yellow pigment content. Markers (ISSR and AFLP) linked with strongest QTL were also converted into SCAR markers for ease of MAS. Blanco et al. [135] detected clusters of QTLs for carotenoid compounds in durum wheat. In 2012, Roncallo et al. [137] reported overlapping of main QTLs affecting flour yellow colour ( $\left.\mathrm{Fb}^{*}\right)$ and GYPC on chromosome arms 4AL, 6AL, 7AS, 7AL, 7BS and 7BL. One QTL on 7BL included $P s y-B 1$ locus also. A novel minor QTL regulating Fb* (located on 7AS) was showing epistatic effect on YPC. One QTL on chromosome 4AL with a strong effect on $\mathrm{Fb}^{*}$ was also involved in two digenic epistatic interactions. Colasuonno et al. [139] mapped a total of seven QTLs on different chromosome regions (1B, 2A, 2B, 5A, 5B, 7A and 7B) using a dense map consisted of 5,670 loci comprising 5,019 SNPs, 467 DArT, 182 SSR markers and eight genes. They also identified two candidate genes involved in carotenoid biosynthesis 
pathway [aldehyde oxidase (AO1), and diphosphomevalonate decarboxylase (DMAPD)] by scanning the genome for QTLs and predicting the SNP homology against annotated proteins in wheat and Brachypodium genomes. Recently, in 2016, in a common wheat population, Zhai et al. [141] mapped sixteen QTLs on chromosome 1B.1R, 2A, 2B, 2D, 5A, 5B, 6B, 7A and 7B, explaining 5.7 to $30.8 \%$ of phenotypic variance for the trait. QTLs for YPC have been mapped on different chromosomes 1A, 1B, 3A, 3B, 7A, 7B and homeologous groups of 2, 4, 5 and 6 chromosomes (Table 3). QTLs, mapped on homoeologous group 7 chromosomes explained up-to $55.22 \%$ of the total phenotypic variation in durum wheat [132] and up to $77 \%$ in common wheat [140] in various biparental populations (Table 3), whereas the QTLs on chromosomes 5B contributed up to $16.2 \%$ [137] and up to $14.8 \%$ [141] in durum and common wheat respectively. Zhai et al. [141] also identified a QTL on 1BL.1RS (H20) explaining 30.8\% of total phenotypic variance. Markers listed in Table 3, would facilitate the selection of improved durum and common varieties. 
Table 3. List of quantitative trait loci (QTL) identified for yellow pigment content.

\begin{tabular}{|c|c|c|c|c|c|c|}
\hline Cross & $\begin{array}{l}\text { Populatio } \\
\text { n type } \\
\text { and size }\end{array}$ & $\begin{array}{l}\text { No. of } \\
\text { total } \\
\text { QTLs }\end{array}$ & $\begin{array}{r}\text { PVE range } \\
\text { (additive } \\
\text { effect QTLs) } \\
\text { Ye }\end{array}$ & $\begin{array}{l}\text { Chromosomes/ } \\
\text { chromosome arms } \\
\text { ow pigment content }\end{array}$ & $\begin{array}{c}\text { Marker intervals / nearest markers for major } \\
\text { QTL (PVE) }\end{array}$ & References \\
\hline $\begin{array}{l}\text { T. aestivum }(\text { Schomburgk) } \times T \text {. } \\
\text { aestivum (Yarralinka) }\end{array}$ & $\begin{array}{l}\text { SSD lines } \\
(150)\end{array}$ & 2 & $13-41$ & $3 \mathrm{~A}, 7 \mathrm{~A}$ & (Xbcd828Đ3А) (13), Xwua16Đ7А.5 (41) & [129] \\
\hline $\begin{array}{l}\text { T. turgidum L. var. durum } \\
\text { (Omrabi5)×T. dicoccoides } \\
\quad(\text { acc.600545) }\end{array}$ & $\begin{array}{l}\text { RILs } \\
(114)\end{array}$ & 3 & $6.0-53.0$ & 7AL, 7BL & Xgwm63e (13), Xgwm34 (53) & [130] \\
\hline $\begin{array}{c}\text { T. aestivum }(\text { Trident }) \times T \text {. aestivum } \\
\text { (Molineux })\end{array}$ & $\begin{array}{l}\text { DH lines } \\
(182)\end{array}$ & 1 & $48-77$ & $7 \mathrm{~B}$ & Xgwm273-Xgwm146 (48-77) & [140] \\
\hline $\begin{array}{l}\text { T. turgidum L. var durum (W9262- } \\
260 \mathrm{D} 3 \times T \text {. turgidum L. var. duram } \\
\text { (Kofa) }\end{array}$ & $\begin{array}{l}\text { DH lines } \\
\quad(155)\end{array}$ & 4 & $14-23$ & $2 \mathrm{~A}, 4 \mathrm{~B}, 6 \mathrm{~B}, 7 \mathrm{~B}$ & $\begin{array}{c}\text { Xgwm495 (14-20), Xgwm425 (15-21), Xgwm193 } \\
\text { (15-21), Psy1-1 (20-23) }\end{array}$ & [131] \\
\hline $\begin{array}{c}\text { T. aestivum }(\mathrm{PH} 82-2) \times T \text {. aestivum } \\
\text { (Neixing 188) }\end{array}$ & $\begin{array}{l}\text { RILs } \\
(240)\end{array}$ & 1 & $20-28$ & 7AS & Xwmc809 (20-28) & [142] \\
\hline $\begin{array}{l}\text { T. turgidum L. var durum (PDW } \\
233) \times T \text {. turgidum L. var durum } \\
\text { (Bhalegaon } 4)\end{array}$ & $\begin{array}{l}\text { RILs } \\
(140)\end{array}$ & 5 & $5-55.22$ & $1 \mathrm{~A}, 3 \mathrm{~B}, 5 \mathrm{~B}, 7 \mathrm{~A}, 7 \mathrm{~B}$ & Xscar3362 (22.61-55.22) & [132] \\
\hline $\begin{array}{l}\text { T. turgidum L. var durum (UC1113) } \\
\times \text { T. turgidum L. var durum (Kofa) }\end{array}$ & RILs (93) & 1 & & $7 \mathrm{~A}$ & Xcfa2293-7A - Xwmc116-7A & [133] \\
\hline $\begin{array}{c}\text { T. aestivum }(\mathrm{PH} 82-2) \times T \text {. aestivum } \\
\text { (Neixiang } 188)\end{array}$ & $\begin{array}{l}\text { RILs } \\
(240)\end{array}$ & 4 & $1.5-33.9$ & $1 \mathrm{~A}, 1 \mathrm{~B}, 4 \mathrm{~A}, 7 \mathrm{~A}$ & Sec1-HVM23 (31.9), Xwmc809-YP7A (33.9) & {$[134]$} \\
\hline $\begin{array}{l}\text { T. turgidum L. var durum ( Latino) } \times \\
\text { T. turgidum L. var durum (Primadur) }\end{array}$ & $\begin{array}{l}\mathrm{F} 2: \mathrm{F} 3 \\
\text { families } \\
(121)\end{array}$ & 5 & $9.4-53.2$ & $2 \mathrm{~A}, 3 \mathrm{~B}, 5 \mathrm{~A}, 7 \mathrm{~A}$ & $\begin{array}{c}\text { Xgwm372-wPt_9797 (11.1-24.5), Xbarc84- } \\
\text { Xgwm299 (11.5-16.2), Xgwm282-wPt_4345 (19.8- } \\
\text { 30.4), D_304196-PsyA1 (42-53.2) }\end{array}$ & [135] \\
\hline $\begin{array}{c}\text { Ajana } \times \text { WAWHT2074; Carnamah } \times \\
\text { WAWHT2046; Ajana } \times \\
\text { WAWHT2046 (all T. aestivum })\end{array}$ & $\begin{array}{c}\text { DH lines } \\
(179,121 \\
127)\end{array}$ & 6 & $4.0-36.0$ & $2 \mathrm{D}, 3 \mathrm{~A}, \underset{7 \mathrm{D}, 5 \mathrm{~B}, 7 \mathrm{~A}}{ }$ & $\begin{array}{c}\text { stm521acat-barc0056 (11-15), wmc25b-gwm484 } \\
\text { (17), wPt6376-wPt9215 (10-21), wPt4038-cfa2257a } \\
\text { (21-36), }\end{array}$ & [136] \\
\hline $\begin{array}{l}\text { T. turgidum L. var durum (UC1113) } \\
\times \text { T. turgidum L. var durum (Kofa) }\end{array}$ & RILs (93) & 15 & $6-42.7$ & $\begin{array}{l}\text { 1BL, 2AS, 4AL } \\
\text { 5AS, 5AL, 5BL } \\
\text { 6AL, 7AS, 7AL } \\
\text { 7BL }\end{array}$ & $\begin{array}{c}\text { BE443797_436-barc302 (10.8), Lpx-A3-wmc617 } \\
\text { (12), wmc219-psr573.2 (12), cfa2040-barc1073 } \\
(15), \text { wmc311-wmc276 (16.9), barc146-gwm132 } \\
(16.8-42.7),\end{array}$ & [137] \\
\hline $\begin{array}{l}\text { T. aestivum (Chuan } 35050) \times T \text {. } \\
\text { aestivum (Shannong } 483 \text { ) }\end{array}$ & $\begin{array}{l}\text { RILs } \\
(131)\end{array}$ & 13 & $4.1-16.5$ & $\begin{array}{l}1 \mathrm{~A}, 1 \mathrm{~B}, 2 \mathrm{D}, 4 \mathrm{~A}, 4 \mathrm{D} \\
5 \mathrm{~B}, 5 \mathrm{D}, 6 \mathrm{~A}, 6 \mathrm{D}, 7 \mathrm{~B}\end{array}$ & $\begin{array}{c}\text { wPt-3931-wPt-665267 (12.1), wPt-3247-wPt-1695 } \\
\text { (16), }\end{array}$ & [138] \\
\hline
\end{tabular}




\begin{tabular}{|c|c|c|c|c|c|c|}
\hline $\begin{array}{l}\text { T. turgidum L. var durum ( Svevo) } \times \\
\text { T. turgidum L. var durum (Ciccio) }\end{array}$ & RILs & 7 & $19.3-51.6^{*}$ & $\begin{array}{c}1 \mathrm{~B}, 2 \mathrm{~A}, 2 \mathrm{~B}, 5 \mathrm{~A}, 5 \mathrm{~B} \\
7 \mathrm{~A}, 7 \mathrm{~B}\end{array}$ & $\begin{array}{c}\text { IWB73028 (19.3), tPt-1253 (21.8), IWB59875 } \\
\text { (51.6) }\end{array}$ & [139] \\
\hline $\begin{array}{l}\text { T. aestivum (Gaocheng } 8901) \times T \text {. } \\
\text { aestivum (Zhoumai 16) }\end{array}$ & $\begin{array}{l}\text { RILs } \\
(176)\end{array}$ & 16 & $5.7-30.8$ & $\begin{array}{l}\text { 1B.1R, 2A, 2B, 2D, } \\
5 \mathrm{~A}, 5 \mathrm{~B}, 6 \mathrm{~B}, 7 \mathrm{~A}, 7 \mathrm{~B}\end{array}$ & $\begin{array}{c}\text { BS00043474_51 (14.1), Ra_c30725_808 (14.8), } \\
\text { Tdurum_contig17230_619 (14.8), BS00065690_51 } \\
\text { (17.2), 1BL.1RS (H20) (30.8), }\end{array}$ & [141] \\
\hline
\end{tabular}

\section{doi:10.20944hregrints201908.0120v1}

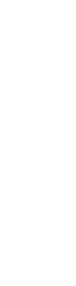

.

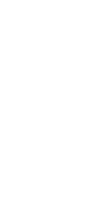

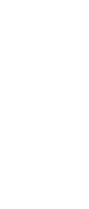




\subsection{Allelic Variation and Marker Assisted Selection}

Allelic variation for GYPC at Psy1-A1, Psy1-B1/Psy1-S1 and Psy1-D1 loci in wheat have been studied in much detail [136, 143]. In 2009, Wang et al. [144] identified 27 allelesassociated with variation in GYPC in wheat. Although several gene/allele-specific markers have been developed with their potential use in improvement of yellow pigment in durum and common wheat [132, 142, 145], studies on marker-assisted development of advanced wheat breeding lines with improved GYPC are lacking [146]. In one study, a short terminal 7EL segment (from Lophopyrum ponticum) translocated to 7A, including Lr19 and Y gene, has been transferred to durum wheat by marker-assisted backcrossing [147]. Patil et al. [148] identified eight alleles of Psy-A1 SSR showing significant association with GYPC and seven alleles for Psy-B1SSR having no association with GYPC in 222 wheat accessions. Further, they introgressed Psy-A1 SSR allele from PDW233 to durum wheat cultivars MACS 3125 and HI 8498, and achieved 89 to $98 \%$ gain in GYPC over recurrent parents.

\section{Biofortification for Grain Phytic Acid Content}

Phytic acid (PA) is primarily the storage form of phosphorus in cereal and legume seeds and accounts for $70 \%$ to $80 \%$ of the total $\mathrm{P}$ in grains $[149,150]$. Phytases are found in the aleurone layers of cereal grains and are activated due to the moisture and hence are inactive in dry cereals due to lack of moisture for their activation. Because of the strong ability of phytic acid to make insoluble complexes of multi-charged metal ions, the consumption of great quantities of food containing high phytic acid levels could produce a deficit in the absorption of these dietary minerals [151]. Cook et al. [152] reported that because of the high phytate content of cereal porridges, iron absorption of native iron and fortification iron might be deficient. Barbro et al. [153] reported that when the phytate is absent zinc absorption rate from our food will increase by 20 percent and magnesium absorption will increase by 60 percent.

\subsection{Genetic Variation and Breeding Strategies}

Breeding opportunities for low phytic acid crops depend on the extent of variation for the same present in germplasm. Ram et al. [154] observed 3.4 fold variations in phytase levels among varieties and 5.9 fold among synthetic hexaploids while investigating a total of four hundred wheat genotypes including released varieties in India, advanced lines and synthetic hexaploids. On the other hand, they observed lower variability (1.6 fold in varieties and 2.2 fold in synthetic hexaploids) in phytate levels. Shitre et al. [155] observed a range of phytic acid from $4.97 \mathrm{mg} / \mathrm{g}$ to $15.02 \mathrm{mg} / \mathrm{g}$ (mean of $9.58 \mathrm{mg} / \mathrm{g}$ ) in 100 advanced breeding lines. This genetic variation for the trait can be utilized for potential breeding of low phytic acid in wheat. Low phytic acid can also be achieved by manipulating the genes involved either in its biosynthesis or its transport in the vacuoles. Genes involved in the late stages of phytic acid biosynthesis pathway are known in crops like maize, soybeans and barley, but none could have been reported from wheat. For the first time, Bhati et al. [156] identified six insilico wheat genes that might be involved in the biosynthesis of inositol phosphates.

Furthermore, they identified a homolog of Zmlpa-1, an ABCC subclass transporter protein (TaMRP3) that is putatively involved in phytic acid transport. Bhati et al. [157] revealed the involvement of $\mathrm{ABCC} 13$ transporter in wheat grain development, phytic acid accumulation and lateral root formation. Naidoo et al. [158] successfully introgressed the lpal-1 gene into tropical and subtropical adapted germplasm using markerassisted selection. They significantly increased the efficiency of detection of the homozygous recessive (99.58\%) and heterozygous (99.59\%) genotypes using SNP as well as improved the recovery of the recurrent parent $(92.15 \%)$ in the BC2F1 generation using AFLP markers in a maize backcross breeding programme. Same types of effort can be made for generating low phytate wheat.

\section{Biofortification for Anthocyanin Content}

Worldwide, grains of common wheat cultivars are amber in colour, and the anthocyanin biofortified wheat is quite uncommon. But now, researchers have started to focus on anthocyanins content in wheat because of their vital importance in human health. These act as antioxidants and prevent from cardiovascular diseases [159], diabetes [160], cancer [161] and obesity [162] etc. Garg et al. [163] developed anthocyanin-rich blue, purple and black wheat lines with alien chromosome or its arm and localized purple and blue colour to the 
pericarp and aleurone, respectively. Combination of genes for both purple and blue colours produce black wheat.

\subsection{Genetic basis of Purple Coloured Wheat Grains}

The genetic base of purple pericarp in wheat has been explored in some detail, some researchers found monogenic [164] and while others reported digenic inheritance for pericarp colour [164, 165]. Dobrovolskaya et al. [164] attempted crosses between purple-grained hexaploid wheat' Purple Feed' - Pp1Pp1/Pp2Pp2, 'Purple' - Pp1Pp1/Pp3Pp3 with non-purple-grained cultivars 'Novosibirskaya 67' ('N67') and 'Saratovskaya 29' ('S29') to map the genes $P p 1, P p 2$, and $P p 3$. Both $P p 2$ and $P p 3$ showing mono-factorial (dominant) inheritance, were mapped in the centromeric region of the chromosome $2 \mathrm{~A}$. Therefore, these two genes were suggested different alleles at the same locus and then designated as $P p 3 a$ and $P p 3 b$. They further reported mutual interaction (9:7) of two dominant genes, $P p 1$ and $P p 3$ in the crosses between purple-grained wheat and 'S29'. Khlestkina et al. [165] mapped Ppl gene on the short arm of chromosome 7B in an F2 population from the durum wheat (Triticum durum) cross TRI 15744/TRI 2719, whereas in common wheat it was reportedly located on 7BL. Mapping suggested that Pp3 gene of T. durum is allelic to the T. aestivum Pp3. Tereshchenko et al. [166] suggested that the $P p$ genes on $T$. durum chromosome $7 \mathrm{~B}$ and $T$. aestivum chromosome 7D are orthologous and designated them Pp-B1 and Pp-D1, respectively. Overall, it can be concluded that the purple pericarp trait in T. aestivum is controlled by genes placed on chromosomes 7D and 2A; still, underlying molecular mechanisms by which they regulate the pericarp colour were remaining unknown.

Marker-assisted backcross strategy was followed to produce a set of bread wheat near-isogenic lines (NILs) carrying various combinations of $P p$ alleles such as $P p 3$ (chr. 2A), $P p-A 1$ (7A) and Pp-D1 (7D) [167]. Based on a qRT-PCR-based study, the authors further suggested that $P p$ genes up-regulate the transcription anthocyanin synthesis structural genes [Chi (chalcone-flavanone isomerase) and $F 3 h$ (flavanone 3hydroxylase)] in contrasting ways.

In 2016, Liu et al. [168] compared the transcriptomes of purple and white pericarps in common wheat and reported significant differential expression of a total of 23,642 unigenes (9945 up-regulated and 13,697 downregulated). The analysis predicted three unigenes of $M Y B$ gene on the long arm of the chromosome $7 \mathrm{~B}$ and three unigenes of $M Y C$ on the long arm of the chromosome $2 \mathrm{~A}$ as candidate genes for the purple grain trait. Further, they also observed a higher expression level of TaMYCl in purple wheat grains compared to white (amber) wheat grains. Shoeva et al. [169] isolated TaMYC1 gene encoding MYC- like transcription factor from the bread wheat genome which was co-located with the Pp3 gene regulating purple pericarp colour. Later on, in 2017, Zong et al. [170] gave additional strong evidence of TaMYC1 to be a synonym of Pp3 and found differences between dominant and recessive Pp3 alleles (TaMYC1p and TaMYC1w). In another study, Li et al. [171] isolated an $M Y B$ transcription factor gene, TaMYB3, localised on chromosome 4BL which induces anthocyanin synthesis in the pericarp cells. Recently, Jiang et al. [172] characterised two transcription factors: TaPpm I (purple pericarp-MYB 1) and TaPpbl (purple pericarp-bHLH 1) in wheat, and it was demonstrated that the interaction of TaPpml and TaPpbl co-regulates the synthesis of anthocyanin in pericarps.

\subsection{Development of Anthocyanin Biofortified Purple Wheat}

Burešová et al. [173] confirmed different chromatin introgressions, carrying genomic regions associated with the production of blue-aleurone, from Thinopyrum ponticum and Triticum monococcum into the background of blue-aleurone wheat elite lines. They analysed a total of 26 blue aleurone wheat lines and reported introgression (ranging from a ditelosomic addition to a disomic substitution, substitution of entire chromosome arms and various translocations) from Th. Ponticum in 17 lines and presumably from $T$. monococcum in nine lines. This study supports a hypothesis that the introgressions activated the blue aleurone trait present in blue aleurone wheat lines, but inactivated, in common wheat germplasm.

Anthocyanin biofortified wheat has attracted the attention of many researchers across the world, but the developed lines exhibit low yield due to linkage drag [174]. In India, Garg et al. [163] developed coloured wheat lines viz. blue, purple and black, with reasonable yield potential and regional adaptation. They transferred genes for blue, purple and wheat pericarps from blue aleurone wheat "TA3972", purple wheat "TA3851" and black wheat to high yielding, disease resistant and locally adapted Indian wheat cultivars PBW550, PBW621 and HD2967. These developed coloured wheat lines exhibited higher anthocyanin content and antioxidant activity (black>purple>blue>white) than donor wheat lines and, high Fe and $\mathrm{Zn}$ content compared to amber wheat cultivars [175]. 


\section{Conclusions}

Within this review, we've compiled the information from the studies carried out in wheat using QTL mapping methodology that is among the best methods for biofortification. Micronutrient deficiency or micronutrient malnutrition or hidden hunger is an increasingly severe global challenge to humankind. As wheat is the major staple food crop in temperate countries and frequently consumed in developing countries, it becomes necessary to biofortify the wheat with micronutrients especially, iron and zinc, for fulfilling the requirement of the human for better health.

In general, there are two major biofortification approaches, first, agronomical biofortification and second genetical biofortification (including conventional breeding, molecular breeding and genetic modification). There is a complex genetic mechanism governing the quantitative traits responsible for the biofortification traits in wheat, and improving biofortification traits of wheat via traditional breeding approaches is also complicated. In this post-genomic and computational systems biology era, specifically, QTL mapping research has helped to dissect the molecular basis of biofortification in wheat. Although, molecular mapping techniques also indicate the co-localization of biofortification related QTLs with some undesirable traits. As a result, the utilisation of genetic variation for biofortification traits with molecular breeding strategy appears to become valuable in future.

Additionally, the existence of substantial genetic variability for biofortification traits also presents superior possibilities to raise the bioavailability of vitamins, minerals and proteins in wheat. The summary of significant QTLs with PVE value $>20 \%$ for biofortification traits are represented in Figure 2. Moreover, biofortification of all relevant QTLs together will require detailed knowledge of the traits and their coexistence; having said that, this also appears to become a promising strategy for the close to future. Therefore, biofortification of wheat may perhaps be enhanced by way of breeding. Additionally, the combination of functional and genetic proof in conjunction with genome sequencing will hopefully deliver additional insights with regards to the emerging biofortification genomics. 


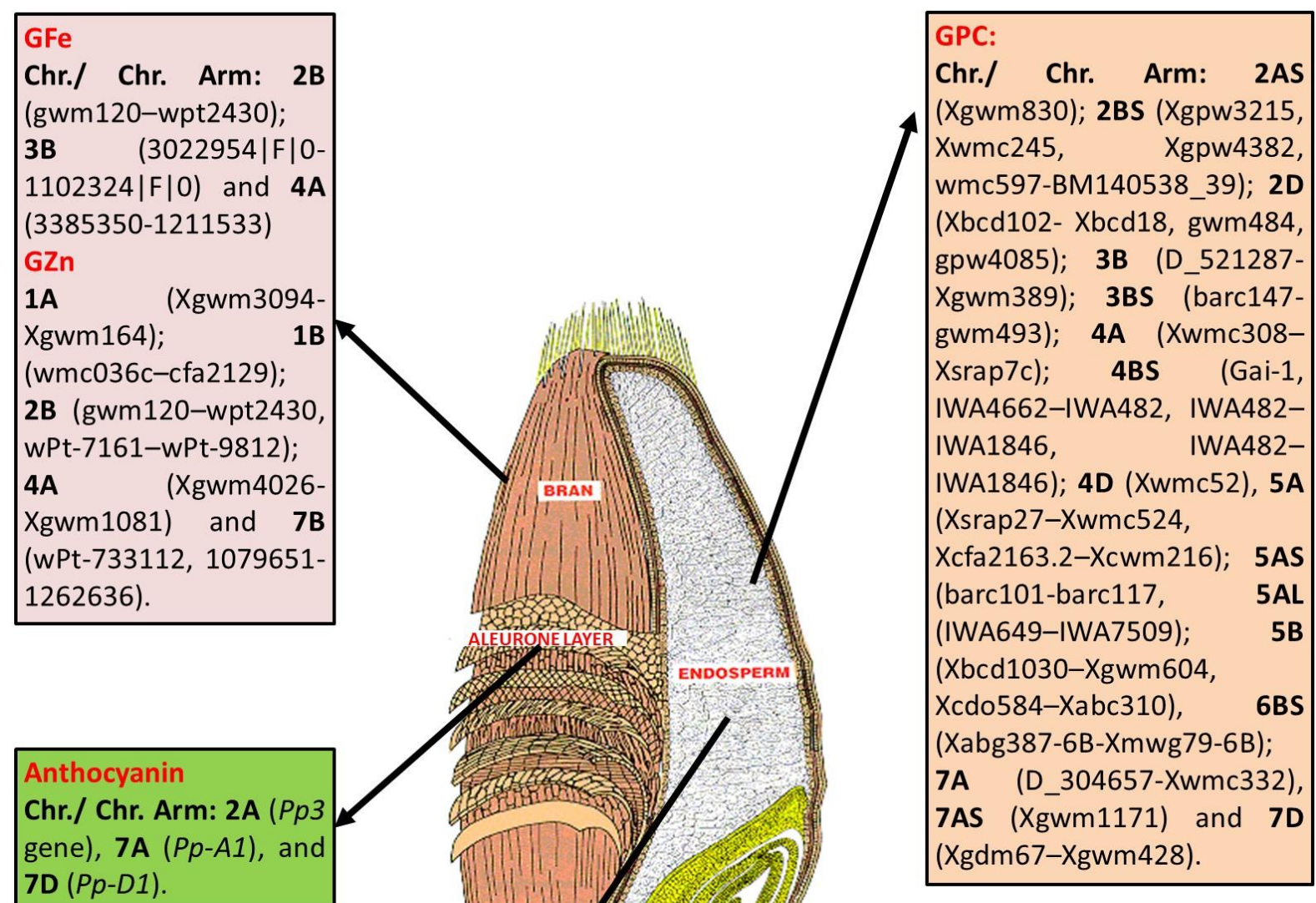

Figure 2. Illustration of the locations of various biofortification traits in wheat grain and closest markers/marker intervals on chromosome associated with the QTLs.

Author Contributions: P.K. conceived of and designed the project. P.K. supervised the study. P.D., D.K.S. and P.K. wrote the paper. P.K. corrected the final draft. All authors read and approved the final manuscript.

Funding: This research received no external funding.

Acknowledgments: The authors are thankful to the anonymous reviewers for their careful reading of the manuscript and providing insightful suggestions.

Conflicts of Interest: The authors declare no conflict of interest. 


\section{References}

1. Grew, R. Food in global history. Routledge. 2018.

2. Bouis, H.E.; Saltzman, A. Improving nutrition through biofortification: A review of evidence from HarvestPlus, 2003 through 2016. Glob. Food Sec. 2017, 12, 49-58.

3. Garg, M.; Sharma, N.; Sharma, S.; Kapoor, P.; Kumar, A.; Chunduri, V.; Arora, P. Biofortified Crops Generated by Breeding, Agronomy, and Transgenic Approaches Are Improving Lives of Millions of People around the World. Front. Nutr. 2018, 5.

4. Hossein-nezhad, A.; Holick, M.F. Vitamin D for Health: A Global Perspective. Mayo Clin. Proc. 2013, 88, $720-755$.

5. Ward, E. Addressing nutritional gaps with multivitamin and mineral supplements. Nutr. J. 2014, 13, 72.

6. de Valença, A.W.; Bake, A.; Brouwer, I.D.; Giller, K.E. Agronomic biofortification of crops to fight hidden hunger in sub-Saharan Africa. Glob Food Sec. 2017, 12, 8-14.

7. Cassman, K.G. Ecological intensification of cereal production systems: Yield potential, soil quality, and precision agriculture. Proc. Natl. Acad. Sci. 1999, 96, 5952-5959.

8. Curtis, T.; Halford, N.G. Food security: the challenge of increasing wheat yield and the importance of not compromising food safety. Ann. Appl. Biol. 2014, 164, 354-372.

9. Iizumi, T.; Furuya, J.; Shen, Z.; Kim, W.; Okada, M.; Fujimori, S.; Hasegawa, T.; Nishimori, M. Responses of crop yield growth to global temperature and socioeconomic changes. Sci. Rep. 2017, 7, 7800.

10. Shewry, P.R.; Hey, S.J. The contribution of wheat to human diet and health. Food Energy Secur. 2015, 4, 178-202.

11. Arora, S.; Cheema, J.; Poland, J.; Uauy, C.; Chhuneja, P. Genome-Wide Association Mapping of Grain Micronutrients Concentration in Aegilops tauschii. Front. Plant Sci. 2019, 10, 54.

12. Fambrini, M.; Pugliesi, C. Carotenoids in Crops: Roles, Regulation of the Pathway, Breeding to Improve the Content. 2009, 1-57.

13. Mellado-Ortega, E.; Hornero-Méndez, D. Lutein esterification in wheat flour increases the carotenoid retention and is induced by storage temperatures. Foods. 2017, 6, 111 .

14. Young, A.J.; Lowe, G.L. Carotenoids-Antioxidant Properties. Antioxidants (Basel). 2018, 28.

15. Shao, Y.; Jin, L.; Zhang, G.; Lu, Y.; Shen, Y.; Bao, J. Association mapping of grain color, phenolic content, flavonoid content and antioxidant capacity in dehulled rice. Theor. Appl. Genet. 2011, 122, 1005-16.

16. Sharma, S.; Chunduri, V.; Kumar, A.; Kumar, R.; Khare, P.; Kondepudi, K.K.; Bishnoi, M.; Garg, M. Anthocyanin bio-fortified colored wheat: Nutritional and functional characterization. PlOS ONE. 2018, 13, e0194367.

17. Cakmak, I.; Kutman, U. Agronomic biofortification of cereals with zinc: a review: Agronomic zinc biofortification. Eur. J. Soil Sci. 2017, 69, 172-180.

18. Goulding, K.; Jarvis, S.; Whitmore, A. Optimizing nutrient management for farm systems. Philos. Trans. R. Soc. Lond. B. Biol. Sci. 2008, 363, 667-680.

19. Deschamps, S.; Llaca, V.; May, G.D. Genotyping-by-Sequencing in Plants. Biology. 2012, 1, 460-483.

20. Hashmi, U.; Shafqat, S.; Khan, F.; Majid, M.; Hussain, H.; Kazi, A.G.; John, R.; Ahmad, P. Plant exomics: Concepts, applications and methodologies in crop improvement. Plant Signal Behav. 2014, 10, e976152.

21. Li, C.; Lin, F.; An, D.; Wang, W.; Huang, R. Genome Sequencing and Assembly by Long Reads in Plants. Genes. 2017a, 9,6 .

22. Klimenko, I.; Razgulayeva, N.; Gau, M.; Okumura, K.; Nakaya, A.; Tabata, S.; Kozlov, N.N.; Isobe, S. Mapping candidate QTLs related to plant persistency in red clover. Theor. Appl. Genet. 2010, 120, 1253-1263.

23. Zhang, S.; Meng, L.; Wang, J.; Zhang, L. Background controlled QTL mapping in pure-line genetic populations derived from four-way crosses. Heredity. 2017, 119, 256-264. 
24. Mondal, S.; Rutkoski, J.E.; Velu, G.; Singh, P.K.; Crespo-Herrera, L.A.; Guzmán, C.; Bhavani, S.; Lan, C.; He, X.; Singh, R.P. Harnessing diversity in wheat to enhance grain yield, climate resilience, disease and insect pest resistance and nutrition through conventional and modern breeding approaches. Front Plant Sci. 2016, 7, 991.

25. Ahmadi, J.; Pour-Aboughadareh, A.; Ourang, S.F.; Mehrabi, A.A.; Siddique, K.H.M. Wild relatives of wheat: Aegilops-Triticum accessions disclose differential antioxidative and physiological responses to water stress. Acta Physiol Plant. 2018, 40, 1-14

26. Dempewolf, H.; Baute, G.; Anderson, J.; Kilian, B.; Smith, C.; Guarino, L. Past and Future Use of Wild Relatives in Crop Breeding. Crop Sci. 2017, 57, 1070-1082.

27. Breseghello, F.; Coelho, A.S.G. Traditional and modern plant breeding methods with examples in rice (Oryza sativa L.). J. Agric. Food Chem. 2013, 61, 8277-8286.

28. Cui, Y.; Zhang, F.; Xu, J.; Li, Z.; Xu, S. Mapping quantitative trait loci in selected breeding populations: A segregation distortion approach. Heredity. 2015, 115, 538-546.

29. Moose, S.P.; Mumm, R.H. Molecular plant breeding as the foundation for 21 st century crop improvement. Plant Physiol. 2008, 147, 969-977.

30. Miles, C.M.; Wayne, M. Quantitative trait locus (QTL) analysis. Nature Education. 2008, 1, 208.

31. Wang, B.; Liu, H.; Liu, Z.; Dong, X.; Guo, J.; Li, W.; Chen, Jing, Gao, C.; Zhu, Y.; Zheng, X.; Chen, Z.; Chen, Jian, Song, W.; Hauck, A.; Lai, J. Identification of minor effect QTLs for plant architecture related traits using super high density genotyping and large recombinant inbred population in maize (Zea mays). BMC Plant Biol. 2018, 18.

32. Ishikawa, A. A Strategy for Identifying Quantitative Trait Genes Using Gene Expression Analysis and Causal Analysis. Genes. 2017, 8, 347.

33. Zhang, X.; Wang, W.; Guo, N.; Zhang, Y.; Bu, Y.; Zhao, J.; Xing, H. Combining QTL-seq and linkage mapping to fine map a wild soybean allele characteristic of greater plant height. BMC Genomics. 2018, 19.

34. Civelek, M.; Lusis, A.J. Systems genetics approaches to understand complex traits. Nat. Rev. Genet. 2014, 15, 34-48.

35. Khan, S.; Nabi, G.; Ullah, M.W.; Yousaf, M.; Manan, S.; Siddique, R.; Hou, H. Overview on the Role of Advance Genomics in Conservation Biology of Endangered Species. Int. J. Genomics. 2016, 1-8.

36. Wambugu, P.W.; Ndjiondjop, M.N.; Henry, R.J. Role of genomics in promoting the utilization of Plant Genetic Resources in genebanks. Brief Funct. Genomics. 2018, 17, 198-206.

37. Consortium (IWGSC), T.I.W.G.S. A chromosome-based draft sequence of the hexaploid bread wheat (Triticum aestivum) genome. Science. 2014, 345, 1251788.

38. Consortium (IWGSC), T.I.W.G.S.; Appels, R.; Eversole, K.; Stein, N.; Feuillet, C.; Keller, B.; Rogers, J. Shifting the limits in wheat research and breeding using a fully annotated reference genome. Science. 2018, 361, 7191.

39. Muir, P.; Li, S.; Lou, S.; Wang, D.; Spakowicz, D.J.; Salichos, L.; Zhang, J.; Weinstock, G.M.; Isaacs, F.; Rozowsky, J.; Gerstein, M. The real cost of sequencing: scaling computation to keep pace with data generation. Genome Biol. 2016, $17,53$.

40. Zhang, J.; Chiodini, R.; Badr, A.; Zhang, G. The impact of next-generation sequencing on genomics. J. Genet. Genomics. 2011, 38, 95-109.

41. Bhatta, M.; Baenziger, P.S.; Waters, B.M.; Poudel, R.; Belamkar, V.; Poland, J.; Morgounov, A. 2018. Genome-Wide Association Study Reveals Novel Genomic Regions Associated with 10 Grain Minerals in Synthetic Hexaploid Wheat. Int. J. Mol. Sci. 2018, 19, 3237.

42. Shewry, P.R. Wheat. J. Exp. Bot. 2009, 60, 1537-1553.

43. Balyan, H.S.; Gupta, P.K.; Kumar, S.; Dhariwal, R.; Jaiswal, V.; Tyagi, S.; Agarwal, P.; Gahlaut, V.; Kumari, S. Genetic improvement of grain protein content and other health-related constituents of wheat grain. Plant Breed. 2013, $132,446-457$. 
44. Blanco, A.; Giovanni, C.D.; Laddomada, B.; Sciancalepore, A.; Simeone, R.; Devos, K.M.; Gale, M.D. Quantitative trait loci influencing grain protein content in tetraploid wheats. Plant Breed. 1996, 115, 310-316.

45. Joppa, L.R.; Du, C.; Hart, G.E.; Hareland, G.A. Mapping gene (s) for grain protein in tetraploid wheat (Triticum turgidum L.) using a population of recombinant inbred chromosome lines. Crop Sci. 1997, 37, 1586-1589.

46. Prasad, M.; Varshney, R.K.; Kumar, A.; Balyan, H.S.; Sharma, P.C.; Edwards, K.J.; Dhaliwal, H.S.; Roy, J.K.; Gupta, P.K. A microsatellite marker associated with a QTL for grain protein content on chromosome arm 2DL of bread wheat. Theor. Appl. Genet. 1999, 99, 341-345.

47. Perretant, M.R.; Cadalen, T.; Charmet, G.; Sourdille, P.; Nicolas, P.; Boeuf, C.; Tixier, M.H.; Branlard, G.; Bernard, S. QTL analysis of bread-making quality in wheat using a doubled haploid population. Theor. Appl. Genet. 2000, 100, 1167-1175.

48. Dholakia, B.B.; Ammiraju, J.S.S.; Santra, D.K.; Singh, H.; Katti, M.V.; Lagu, M.D.; Tamhankar, S.A.; Rao, V.S.; Gupta, V.S.; Dhaliwal, H.S.; Ranjekar, P.K. Molecular marker analysis of protein content using PCR-based markers in wheat. Biochem Genet. 2001, 39, 325-338.

49. Singh, H.; Prasad, M.; Varshney, R.K.; Roy, J.K.; Balyan, H.S.; Dhaliwal, H.S.; Gupta, P.K. STMS markers for grain protein content and their validation using near-isogenic lines in bread wheat. Plant Breed. 2001, 120, 273-278.

50. Blanco, A.; Pasqualone, A.; Troccoli, A.; Di Fonzo, N.; Simeone, R. Detection of grain protein content QTLs across environments in tetraploid wheats. Plant Mol Biol. 2002, 48, 615-623.

51. Börner, A.; Schumann, E.; Fürste, A.; Cöster, H.; Leithold, B.; Röder, M.; Weber, W. Mapping of quantitative trait loci determining agronomic important characters in hexaploid wheat (Triticum aestivum L.). Theor. Appl. Genet. 2002, 105, 921-936.

52. Groos, C.; Robert, N.; Bervas, E.; Charmet, G. Genetic analysis of grain protein-content, grain yield and thousandkernel weight in bread wheat. Theor. Appl. Genet. 2003. 106, 1032-1040.

53. Prasad, M.; Kumar, N.; Kulwal, P.; Röder, M.; Balyan, H.; Dhaliwal, H.; Gupta, P. QTL analysis for grain protein content using SSR markers and validation studies using NILs in bread wheat. Theor. Appl. Genet. 2003, 106, 659667.

54. Gonzalez-Hernandez, J.L.; Elias, E.M.; Kianian, S.F. Mapping genes for grain protein concentration and grain yield on chromosome 5B of Triticum turgidum (L.) var. dicoccoides. Euphytica. 2004, 139, 217-225.

55. Groos, C.; Bervas, E.; Charmet, G. Genetic analysis of grain protein content, grain hardness and dough rheology in a hard $\times$ hard bread wheat progeny. J. Cereal Sci. 2004, 40, 93-100.

56. Kulwal, P.; Kumar, N.; Kumar, A.; Gupta, R.K.; Balyan, H.S.; Gupta, P.K. Gene networks in hexaploid wheat: interacting quantitative trait loci for grain protein content. Funct Integr Genomics. 2005, 5, 254-259.

57. Huang, X.Q.; Cloutier, S.; Lycar, L.; Radovanovic, N.; Humphreys, D.G.; Noll, J.S.; Somers, D.J.; Brown, P.D. Molecular detection of QTLs for agronomic and quality traits in a doubled haploid population derived from two Canadian wheats (Triticum aestivum L.). Theor. Appl. Genet. 2006, 113, 753-766.

58. Nelson, J.C.; Andreescu, C.; Breseghello, F.; Finney, P.L.; Gualberto, D.G.; Bergman, C.J.; Pena, R.J.; Perretant, M.R.; Leroy, P.; Qualset, C.O.; Sorrells, M.E. Quantitative trait locus analysis of wheat quality traits. Euphytica. 2006, $149,145-159$.

59. Laperche, A.; Brancourt-Hulmel, M.; Heumez, E.; Gardet, O.; Hanocq, E.; Devienne-Barret, F.; Le Gouis, J. Using genotypex nitrogen interaction variables to evaluate the QTL involved in wheat tolerance to nitrogen constraints. Theor. Appl. Genet. 2007, 115, 399-415.

60. Sun, H.; Lü, J.; Fan, Y.; Zhao, Y.; Kong, F.; Li, R.; Wang, H.; Li, S. Quantitative trait loci (QTLs) for quality traits related to protein and starch in wheat. Prog Nat Sci-Mater., 2008, 18, 825-831.

61. Li, Y.; Song, Y.; Zhou, R.; Branlard, G.; Jia, J. Detection of QTLs for bread-making quality in wheat using a recombinant inbred line population. Plant Breed. 2009, 128, 235-243. 
62. Mann, G.; Diffey, S.; Cullis, B.; Azanza, F.; Martin, D.; Kelly, A.; McIntyre, L.; Schmidt, A.; Ma, W.; Nath, Z.; Kutty, I. Genetic control of wheat quality: interactions between chromosomal regions determining protein content and composition, dough rheology, and sponge and dough baking properties. Theoretical and Applied Genetics. 2009, 118, 1519-1537.

63. Patil, R.M.; Oak, M.D.; Tamhankar, S.A.; Rao, V.S. Molecular mapping of QTLs for gluten strength as measured by sedimentation volume and mixograph in durum wheat (Triticum turgidum L. ssp durum). J. Cereal Sci. 2009, 49, 378386.

64. Peleg, Z.; Cakmak, I.; Ozturk, L.; Yazici, A.; Jun, Y.; Budak, H.; Korol, A.B.; Fahima, T.; Saranga, Y. Quantitative trait loci conferring grain mineral nutrient concentrations in durum wheat $\times$ wild emmer wheat RIL population. Theor. Appl. Genet. 2009, 119, 353-369.

65. Raman, R.; Allen, H.; Diffey, S.; Raman, H.; Martin, P.; McKelvie, K. Localisation of quantitative trait loci for quality attributes in a doubled haploid population of wheat (Triticum aestivum L.). Genome. 2009, 52, 701-715.

66. Suprayogi, Y.; Pozniak, C.J.; Clarke, F.R.; Clarke, J.M.; Knox, R.E.; Singh, A.K. Identification and validation of quantitative trait loci for grain protein concentration in adapted Canadian durum wheat populations. Theor. Appl. Genet. 2009, 119, 437-448.

67. Sun, X.; Marza, F.; Ma, H.; Carver, B.F.; Bai, G. Mapping quantitative trait loci for quality factors in an inter-class cross of US and Chinese wheat. Theor. Appl. Genet. 2010, 120, 1041-1051.

68. Tsilo, T.J.; Hareland, G.A.; Simsek, S.; Chao, S.; Anderson, J.A. Genome mapping of kernel characteristics in hard red spring wheat breeding lines. Theor. Appl. Genet. 2010, 121, 717-730.

69. Zhao, L.; Zhang, K.P.; Liu, B.; Deng, Z.Y.; Qu, H.L.; Tian, J.C. A comparison of grain protein content QTLs and flour protein content QTLs across environments in cultivated wheat. Euphytica. 2010, 174, 325-335.

70. Conti, V.; Roncallo, P.F.; Beaufort, V.; Cervigni, G.L.; Miranda, R.; Jensen, C.A.; Echenique, V.C. Mapping of main and epistatic effect QTLs associated to grain protein and gluten strength using a RIL population of durum wheat. J. Appl. Genet. 2011, 52, 287-298.

71. Blanco, A.; Mangini, G.; Giancaspro, A.; Giove, S.; Colasuonno, P.; Simeone, R.; Signorile, A.; De Vita, P.; Mastrangelo, A.M.; Cattivelli, L.; Gadaleta, A. Relationships between grain protein content and grain yield components through quantitative trait locus analyses in a recombinant inbred line population derived from two elite durum wheat cultivars. Mol. Breed. 2012, 30, 79-92.

72. Golabadi, M.; Arzani, A.; Mirmohammadi Maibody, S. Identification of microsatellite markers associated with grain protein content in durum wheat grown under drought stress at terminal growth stages. Cereal Res. Commun. 2012, 40, 215-224.

73. Li, J.; Cui, F.; Ding, A.M.; Zhao, C.H.; Wang, X.Q.; Wang, L.; Bao, Y.G.; Qi, X.L.; Li, X.F.; Gao, J.R.; Feng, D.S. QTL detection of seven quality traits in wheat using two related recombinant inbred line populations. Euphytica. 2012a, 183, 207-226.

74. Li, Y.; Zhou, R.; Wang, J.; Liao, X.; Branlard, G.; Jia, J. Novel and favorable QTL allele clusters for end-use quality revealed by introgression lines derived from synthetic wheat. Mol. Breed. 2012b, 29, 627-643.

75. Simons, K.; Anderson, J.A.; Mergoum, M.; Faris, J.D.; Klindworth, D.L.; Xu, S.S.; Sneller, C.; Ohm, J.B.; Hareland, G.A.; Edwards, M.C.; Chao, S. Genetic mapping analysis of bread-making quality traits in spring wheat. Crop Sci. 2012, 52, 2182-2197.

76. Wang, L.I.N.; Cui, F.A.; Wang, J.; Jun, L.I.; Ding, A.; Zhao, C.; Li, X.; Feng, D.; Gao, J.; Wang, H. Conditional QTL mapping of protein content in wheat with respect to grain yield and its components. J. Genet. 2012, 91, 303-312.

77. Xu, Y.; An, D.; Liu, D.; Zhang, A.; Xu, H. and Li, B. Molecular mapping of QTLs for grain zinc, iron and protein concentration of wheat across two environments. Field Crops Res. 2012, 138, 57-62. 
78. El-Feki, W.M.; Byrne, P.F.; Reid, S.D.; Lapitan, N.L.; Haley, S.D. Quantitative trait locus mapping for end-use quality traits in hard winter wheat under contrasting soil moisture levels. Crop Sci. 2013, 53, 1953-1967.

79. Heo, H.; Sherman, J. Identification of QTL for grain protein content and grain hardness from winter wheat for genetic improvement of spring wheat. Plant Breed Biotechnol. 2013, 1, 347-353.

80. Deng, Z.; Hu, S.; Chen, F.; Li, W.; Chen, J.; Sun, C.; Zhang, Y.; Wang, S.; Song, X.; Tian, J. Genetic dissection of interaction between wheat protein and starch using three mapping populations. Mol. Breed. 2015, 35, 12.

81. Maphosa, L.; Langridge, P.; Taylor, H.; Emebiri, L.C.; Mather, D.E. Genetic control of grain protein, dough rheology traits and loaf traits in a bread wheat population grown in three environments. J Cereal Sci. 2015, 64, 147-152.

82. Moore, C.M.; Richards, R.A.; Rebetzke, G.J. Phenotypic variation and QTL analysis for oil content and protein concentration in bread wheat (Triticum aestivum L.). Euphytica. 2015, 204, 371-382.

83. Echeverry-Solarte, M.; Kumar, A.; Kianian, S.; Simsek, S.; Alamri, M.S.; Mantovani, E.E.; McClean, P.E.; Deckard, E.L.; Elias, E.; Schatz, B.; Xu, S.S. New QTL alleles for quality-related traits in spring wheat revealed by RIL population derived from supernumerary $\times$ non-supernumerary spikelet genotypes. Theor. Appl. Genet. 2015, 128, 893912.

84. Li, C.; Bai, G.; Chao, S.; Carver, B.; Wang, Z. Single nucleotide polymorphisms linked to quantitative trait loci for grain quality traits in wheat. The Crop Journal. 2016, 4, 1-11.

85. Mahjourimajd, S.; Taylor, J.; Rengel, Z.; Khabaz-Saberi, H.; Kuchel, H.; Okamoto, M.; Langridge, P. The genetic control of grain protein content under variable nitrogen supply in an Australian wheat mapping population. PloS one. 2016, 11, p.e0159371.

86. Terasawa, Y.; Ito, M.; Tabiki, T.; Nagasawa, K.; Hatta, K.; Nishio, Z. Mapping of a major QTL associated with protein content on chromosome 2B in hard red winter wheat (Triticum aestivum L.). Breeding Sci. 2016, 66, 471-480.

87. Tiwari, C.; Wallwork, H.; Arun, B.; Mishra, V.K.; Velu, G.; Stangoulis, J.; Kumar, U. and Joshi, A.K.; Molecular mapping of quantitative trait loci for zinc, iron and protein content in the grains of hexaploid wheat. Euphytica. 2016, 207, 563-570.

88. Sun, X.; Wu, K.; Zhao, Y.; Qian, Z.; Kong, F.; Guo, Y.; Wang, Y.; Li, S. Molecular genetic analysis of grain protein content and flour whiteness degree using RILs in common wheat. J. Genet. 2016, 95, 317-324.

89. Marcotuli, I.; Gadaleta, A.; Mangini, G.; Signorile, A.; Zacheo, S.; Blanco, A.; Simeone, R.; Colasuonno, P. Development of a high-density SNP-based linkage map and detection of QTL for $\beta$-glucans, protein content, grain yield per spike and heading time in durum wheat. Int. J. Mol. Sci. 2017, 18, 1329.

90. Dao, H.Q.; Byrne, P.F.; Reid, S.D.; Haley, S.D. Validation of quantitative trait loci for grain quality-related traits in a winter wheat mapping population. Euphytica. 2017, 213, 5.

91. Wang, D.L.; Zhu, J.; Li, Z.K.L.; Paterson, A.H. Mapping QTLs with epistatic effects and QTL $\times$ environment interactions by mixed linear model approaches. Theor. Appl. Genet. 1999, 99, 1255-1264.

92. Yang, J.; Hu, C.; Hu, H.; Yu, R.; Xia, Z.; Ye, X; Zhu, J. QTL Network: mapping and visualizing genetic architecture of complex traits in experimental populations. Bioinformatics. 2008, 24, 721-723.

93. Meng, L.; Li, H.; Zhang, L.; Wang, J. QTL IciMapping: Integrated software for genetic linkage map construction and quantitative trait locus mapping in biparental populations. The Crop Journal. 2015, 3, 269-283.

94. Avivi, L. High protein content in wild tetraploid Triticum dicoccoides Korn. In: Ramanujam S (ed) Proceedings of the $5^{\text {th }}$ international wheat genetics symposium. Indian Society of Genetics and Plant Breeding (ISGPB), New Delhi, India, 1978, 372-380.

95. Joppa, L.R.; Cantrell, R.G. Chromosomal location of genes for grain protein content of wild tetraploid wheat. Crop Sci. 1990, 30, 1059-1064.

96. Olmos, S.; Distelfeld, A.; Chicaiza, O.; Schlatter, A.R.; Fahima, T.; Echenique, V.; Dubcovsky, J. Precise mapping of a locus affecting grain protein content in durum wheat. Theor. Appl. Genet. 2003, 107, 1243-1251. 
97. Uauy, C.; Distelfeld, A.; Fahima, T.; Blechl, A.; Dubcovsky, J. A NAC gene regulating senescence improves grain protein, zinc, and iron content in wheat. Science. 2006, 314, 1298-1301.

98. Tabbita, F.; Pearce, S.; Barneix, A.J. Breeding for increased grain protein and micronutrient content in wheat: ten years of the GPC-B1 gene. J. Cereal Sci. 2017, 73, 183-191.

99. Zhang, Y.Q.; Sun, Y.X.; Ye, Y.L. Zinc biofortification of wheat through fertilizer applications in different locations of China. Field Crops Res. 2012, 125, 1-7.

100. Zou, C.Q.; Zhang, Y.Q.; Rashid, A.; Ram, H.; Savasli, E.; Arisoy, R.Z.; Ortiz-Monasterio, I.; Simunji, S.; Wang, Z.H.; Sohu, V. and Hassan, M. Biofortification of wheat with zinc through zinc fertilization in seven countries. Plant Soil. 2012, 361, 119-130.

101. Zhang, Y.; Shi, R.; Rezaul, K.M.; Zhang, F.; Zou, C. Iron and zinc concentrations in grain and flour of winter wheat as affected by foliar application. J. Agric. Food Chem. 2010, 58, 12268-12274.

102. Aciksoz, S.B.; Yazici, A.; Ozturk, L.; Cakmak, I. Biofortification of wheat with iron through soil and foliar application of nitrogen and iron fertilizers. Plant and Soil. 2011, 349, 215-225.

103. Singh, R., Govindan, V. and Andersson, M.S. Zinc-biofortified wheat: harnessing genetic diversity for improved nutritional quality 2017 (No. 2187-2019-666).

104. Lowe, N.M.; Khan, M.J.; Broadley, M.R.; Zia, M.H.; McArdle, H.J.; Joy, E.J.; Ohly, H.; Shahzad, B.; Ullah, U.; Kabana, G.; Medhi, R. Examining the effectiveness of consuming flour made from agronomically biofortified wheat (Zincol-2016/NR-421) for improving Zn status in women in a low-resource setting in Pakistan: study protocol for a randomised, double-blind, controlled cross-over trial (BiZiFED). BMJ open. 2018, 8, e021364.

105. Shi, R.; Li, H.; Tong, Y.; Jing, R.; Zhang, F.; Zou, C. Identification of quantitative trait locus of zinc and phosphorus density in wheat (Triticum aestivum L.) grain. Plant and soil. 2008, 306, 95-104.

106. Tiwari, V.K.; Rawat, N.; Chhuneja, P.; Neelam, K.; Aggarwal, R.; Randhawa, G.S.; Dhaliwal, H.S.; Keller, B.; Singh, K. Mapping of quantitative trait loci for grain iron and zinc concentration in diploid A genome wheat. J. Hered. 2009, $100,771-776$.

107. Pu, Z.E.; Ma, Y.U.; He, Q.Y.; Chen, G.Y.; Wang, J.R.; Liu, Y.X.; Jiang, Q.T.; Wei, L.I.; Dai, S.F.; Wei, Y.M.; Zheng, Y.L. Quantitative trait loci associated with micronutrient concentrations in two recombinant inbred wheat lines. $J$ Integr Agric. 2014, 13, 2322-2329.

108. Crespo-Herrera, L.A.; Govindan, V.; Stangoulis, J.; Hao, Y.; Singh, R.P. QTL mapping of grain Zn and Fe concentrations in two hexaploid wheat RIL populations with ample transgressive segregation. Front. Plant Sci. 2017, 8,1800 .

109. Krishnappa, G.; Singh, A.M.; Chaudhary, S.; Ahlawat, A.K.; Singh, S.K.; Shukla, R.B.; Jaiswal, J.P.; Singh, G.P.; Solanki, I.S. Molecular mapping of the grain iron and zinc concentration, protein content and thousand kernel weight in wheat (Triticum aestivum L.). PloS one. 2017, 12, e0174972.

110. Crespo-Herrera, L.A.; Velu, G.; Singh, R.P. Quantitative trait loci mapping reveals pleiotropic effect for grain iron and zinc concentrations in wheat. Ann Appl Biol. 2016, 169, 27-35.

111. Velu, G.; Tutus, Y.; Gomez-Becerra, H.F.; Hao, Y.; Demir, L.; Kara, R.; Crespo-Herrera, L.A.; Orhan, S.; Yazici, A.; Singh, R.P.; Cakmak, I. QTL mapping for grain zinc and iron concentrations and zinc efficiency in a tetraploid and hexaploid wheat mapping populations. Plant Soil. 2017, 411, 81-99.

112. Genc, Y.; Verbyla, A.P.; Torun, A.A.; Cakmak, I.; Willsmore, K.; Wallwork, H.; McDonald, G.K. Quantitative trait loci analysis of zinc efficiency and grain zinc concentration in wheat using whole genome average interval mapping. Plant Soil. 2009, 314, 49.

113. Shi, R.L.; Tong, Y.P.; Jing, R.L.; Zhang, F.S.; Zou, C.Q. Characterization of quantitative trait loci for grain minerals in hexaploid wheat (Triticum aestivum L.). J. Integr. Agric. 2013, 12, 1512-1521. 
114. Roshanzamir, H.; Kordenaeej, A.; Bostani, A. Mapping QTLs related to Zn and Fe concentrations in bread wheat (Triticum aestivum) grain using microsatellite markers. Iran. J. Genet. Plant Breed. 2013, 2, 10-17.

115. Hao, Y.; Velu, G.; Peña, R.J.; Singh, S.; Singh, R.P. Genetic loci associated with high grain zinc concentration and pleiotropic effect on kernel weight in wheat (Triticum aestivum L.). Mol. Breed. 2014, 34, 1893-1902.

116. Srinivasa, J.; Arun, B.; Mishra, V.K.; Singh, G.P.; Velu, G.; Babu, R.; Vasistha, N.K.; Joshi, A.K. Zinc and iron concentration QTL mapped in a Triticum speltax T. aestivum cross. Theor. Appl. Genet. 2014, 127, 1643-1651.

117. Wang, P.; Wang, H.; Liu, Q.; Tian, X.; Shi, Y.; Zhang, X. QTL mapping of selenium content using a RIL population in wheat. Plos One. 2017, 12, p.e0184351.

118. Pu, Z.; Pei, Y.; Yang, J.; Ma, J.; Li, W.; Liu, D.; Wang, J.; Wei, Y.; Zheng, Y. A QTL located on chromosome 3D enhances the selenium concentration of wheat grain by improving phytoavailability and root structure. Plant and soil. 2018, 425, 287-296.

119. Yan, J.; Xue, W.T.; Yang, R.Z.; Qin, H.B.; Zhao, G.; Tzion, F.; Cheng, J.P. Quantitative trait loci conferring grain selenium nutrient in durum wheat× wild emmer wheat RIL population. Czech J. Genet. Plant Breed. 2018, 54, 52-58.

120. Gorafi, Y.S.; Ishii, T.; Kim, J.S.; Elbashir, A.A.E.; Tsujimoto, H. Genetic variation and association mapping of grain iron and zinc contents in synthetic hexaploid wheat germplasm. Plant Genet. Resour. 2018, 16, 9-17.

121. Magallanes-López, A.M.; Hernandez-Espinosa, N.; Velu, G.; Posadas-Romano, G.; Ordoñez-Villegas, V.M.G.; Crossa, J.; Ammar, K.; Guzmán, C. Variability in iron, zinc and phytic acid content in a worldwide collection of commercial durum wheat cultivars and the effect of reduced irrigation on these traits. Food chemistry. 2017, 237, 499505 .

122. Amiri, R.; Bahraminejad, S.; Cheghamirza, K. Estimating genetic variation and genetic parameters for grain iron, zinc and protein concentrations in bread wheat genotypes grown in Iran. J. Cereal Sci. 2018, 80, 16-23.

123. Zhao, J.X.; Xing, H.J.; Liu, C.P.; Zhang, Z.W.; Xu, S.W. Effect of Selenium Deficiency on Nitric Oxide and Heat Shock Proteins in Chicken Erythrocytes. Biol. Trace Elem. Res. 2016, 171, 208-213.

124. Noble, R.M.; Barry, G.A. Survey of selenium concentrations in wheat, sorghum and soybean grains, prepared poultry feeds and feed ingredients from Queensland. Queensland Journal of Agricultural and Animal Sciences (Australia). 1982.

125. Tveitnes, S.; Singh, B.R.; Ruud, L. Selenium concentration in spring wheat as influenced by basal application and top dressing of selenium-enriched fertilizers. Fert Res. 1995, 45, 163-167.

126. Piergiovanni, A.R.; Rizzi, R.; Pannacciulli, E.; Gatta, C.D. Mineral composition in hulled wheat grains: a comparison between emmer (Triticum dicoccon Schrank) and spelt (T. spelta L.) accessions. Int. J. Food Sci. Nutr. 1997, 48, 381386.

127. Lyons, G.; Ortiz-Monasterio, I.; Stangoulis, J.; Graham, R. Selenium concentration in wheat grain: is there sufficient genotypic variation to use in breeding? Plant and Soil. 2005, 269, 369-380.

128. Yeum, K.J.; Russell, R.M. Carotenoid bioavailability and bioconversion. Annu. Rev. Nutr. 2002, 22, 483-504.

129. Parker, G.D.; Chalmers, K.J.; Rathjen, A.J.; Langridge, P. Mapping loci associated with flour colour in wheat (Triticum aestivum L.). Theor. Appl. Genet. 1998, 97, 238-245.

130. Elouafi, I.; Nachit, M.M.; Martin, L.M. Identification of a microsatellite on chromosome 7B showing a strong linkage with yellow pigment in durum wheat (Triticum turgidum L. var. durum). Hereditas. 2001, 135, 255-261.

131. Pozniak, C.J.; Knox, R.E.; Clarke, F.R.; Clarke, J.M. Identification of QTL and association of a phytoene synthase gene with endosperm colour in durum wheat. Theor. Appl. Genet. 2007, 114, 525-537.

132. Patil, R.M.; Oak, M.D.; Tamhankar, S.A.; Sourdille, P.; Rao, V.S. Mapping and validation of a major QTL for yellow pigment content on 7AL in durum wheat (Triticum turgidum L. ssp. durum). Mol. Breed. 2008, 21, 485-496.

133. Zhang, W.; Dubcovsky, J. Association between allelic variation at the Phytoene synthase 1 gene and yellow pigment content in the wheat grain. Theor. Appl. Genet. 2008, 116, 635-645. 
134. Zhang, Y.; Wu, Y.; Xiao, Y.; He, Z.; Zhang, Y.; Yan, J.; Zhang, Y.; Xia, X.; Ma, C. QTL mapping for flour and noodle colour components and yellow pigment content in common wheat. Euphytica. 2009, 165, 435.

135. Blanco, A.; Colasuonno, P.; Gadaleta, A.; Mangini, G.; Schiavulli, A.; Simeone, R.; Digesù, A.M.; De Vita, P.; Mastrangelo, A.M.; Cattivelli, L. Quantitative trait loci for yellow pigment concentration and individual carotenoid compounds in durum wheat. J. Cereal Sci. 2011, 54, 255-264.

136. Crawford, A.C.; Stefanova, K.; Lambe, W.; McLean, R.; Wilson, R.; Barclay, I.; Francki, M.G. Functional relationships of phytoene synthase 1 alleles on chromosome 7A controlling flour colour variation in selected Australian wheat genotypes. Theor. Appl. Genet. 2011, 123, 95.

137. Roncallo, P.F.; Cervigni, G.L.; Jensen, C.; Miranda, R.; Carrera, A.D.; Helguera, M.; Echenique, V. QTL analysis of main and epistatic effects for flour color traits in durum wheat. Euphytica. 2012, 185, 77-92.

138. Zhao, Y.; Sun, H.Y.; Wang, Y.Y.; Pu, Y.Y.; Kong, F.M.; Li, S.S. QTL mapping for the color, carotenoids and polyphenol oxidase activity of flour in recombinant inbred lines of wheat. Aust. J. Crop Sci. 2013, 7, 328.

139. Colasuonno, P.; Gadaleta, A.; Giancaspro, A.; Nigro, D.; Giove, S.; Incerti, O.; Mangini, G.; Signorile, A.; Simeone, R.; Blanco, A. Development of a high-density SNP-based linkage map and detection of yellow pigment content QTLs in durum wheat. Mol. Breed. 2014, 34, 1563-1578.

140. Kuchel, H.; Langridge, P.; Mosionek, L.; Williams, K.; Jefferies, S.P. The genetic control of milling yield, dough rheology and baking quality of wheat. Theor. Appl. Genet. 2006, 112, 1487.

141. Zhai, S.; He, Z.; Wen, W.; Jin, H.; Liu, J.; Zhang, Y.; Liu, Z.; Xia, X. Genome-wide linkage mapping of flour colorrelated traits and polyphenol oxidase activity in common wheat. Theor. Appl. Genet. 2016a, 129, 377-394.

142. He, X.Y.; Zhang, Y.L.; He, Z.H.; Wu, Y.P.; Xiao, Y.G.; Ma, C.X.; Xia, X.C. Characterization of phytoene synthase 1 gene (Psy1) located on common wheat chromosome 7A and development of a functional marker. Theor. Appl. Genet. 2008, 116, 213-221.

143. Ficco, D.B.; Mastrangelo, A.M.; Trono, D.; Borrelli, G.M.; De Vita, P.; Fares, C.; Beleggia, R.; Platani, C.; Papa, R. The colours of durum wheat: a review. Crop Pasture Sci. 2014, 65, 1-15.

144. Wang, J.; He, X.; He, Z.; Wang, H.; Xia, X. Cloning and phylogenetic analysis of phytoene synthase 1 (Psy1) genes in common wheat and related species. Hereditas. 2009, 146, 208-256.

145. Singh, A.; Reimer, S.; Pozniak, C.J.; Clarke, F.R.; Clarke, J.M.; Knox, R.E.; Singh, A.K. Allelic variation at Psy1-A1 and association with yellow pigment in durum wheat grain. Theor. Appl. Genet. 2009, 118, 1539-1548.

146. Zhai, S.; Xia, X.; He, Z. Carotenoids in staple cereals: metabolism, regulation, and genetic manipulation. Front. Plant Sci. 2016b, 7, 1197.

147. Zhang, W.; Lukaszewski, A.J.; Kolmer, J.; Soria, M.A.; Goyal, S.; Dubcovsky, J. Molecular characterization of durum and common wheat recombinant lines carrying leaf rust resistance (Lr19) and yellow pigment (Y) genes from Lophopyrum ponticum. Theor. Appl. Genet. 2005, 111, 573-582.

148. Patil, R.; Oak, M.; Deshpande, A.; Tamhankar, S. Development of a robust marker for Psy-1 homoeologs and its application in improvement of yellow pigment content in durum wheat. Mol. Breed. 2018, 38, 136.

149. Lolas, G.M.; Palmidis, N.; Markakis, P. The Phytic Acid-Total Phosphorus Relationship in Barley, Oats, Soybeans, and Wheat. Cereal Chem. 1976, 53, 867-871.

150. Raboy, V.; Noaman, M.W.; Taylor, G.A.; Pickett, S.G. Grain phytic acid and protein are highly correlated in winter wheat. Crop Sci. 1991, 31, 631-635.

151. Reddy, N.R.; Pierson, M.D. Reduction in antinutritional and toxic components in plant foods by fermentation. Food Res. Int. 1994, 27, 281-290.

152. Cook, J.D.; Reddy, M.B.; Burri, J.; Juillerat, M.A.; Hurrell, R.F. The influence of different cereal grains on iron absorption from infant cereal foods. Am. J. Clin. Nutr. 1997, 65, 964-969. 
153. Barbro, N.; Brittmarie, S.; Cederblad, Å.K.E. Reduction of the phytate content of bran by leavening in bread and its effect on zinc absorption in man. Br J Nutr. 1985, 53, 47-53.

154. Ram, S.; Verma, A.; Sharma, S. Large variability exits in phytase levels among Indian wheat varieties and synthetic hexaploids. J. Cereal Sci. 2010, 52, 486-490.

155. Shitre, A.S.; Gadekar, D.A.; Vikas, V.R.; Bakshi, S.; Kumar, V.; Vishwakarma, G.; Das, B.K. Genotypic variation for phytic acid, inorganic phosphate and mineral contents in advanced breeding lines of wheat (Triticum aestivum L.). Electronic J. Plant Breed. 2015, 6, 395-402.

156. Bhati, K.K.; Aggarwal, S.; Sharma, S.; Mantri, S.; Singh, S.P.; Bhalla, S.; Kaur, J.; Tiwari, S.; Roy, J.K.; Tuli, R.; Pandey, A.K. Differential expression of structural genes for the late phase of phytic acid biosynthesis in developing seeds of wheat (Triticum aestivum L.). Plant Sci. 2014, 224, 74-85.

157. Bhati, K.K.; Alok, A.; Kumar, A.; Kaur, J.; Tiwari, S.; Pandey, A.K. Silencing of ABCC13 transporter in wheat reveals its involvement in grain development, phytic acid accumulation and lateral root formation. J. Exp. Bot. 2016, 67, 4379-4389.

158. Naidoo, R.; Watson, G.M.F.; Derera, J.; Tongoona, P.; Laing, M.D. Marker-assisted selection for low phytic acid (lpa1-1) with single nucleotide polymorphism marker and amplified fragment length polymorphisms for background selection in a maize backcross breeding programme. Mol. Breed. 2012, 30, 1207-1217.

159. Kris-Etherton, P.M.; Lefevre, M.; Beecher, G.R.; Gross, M.D.; Keen, C.L.; Etherton, T.D. Bioactive compounds in nutrition and health-research methodologies for establishing biological function: the antioxidant and antiinflammatory effects of flavonoids on atherosclerosis. Annu. Rev. Nutr. 2004, 24, 511-538.

160. Patel, K.; Jain, A.; Patel, D.K. Medicinal significance, pharmacological activities, and analytical aspects of anthocyanidins 'delphinidin': A concise report. J Acute Dis. 2013, 2, 169-178.

161. Arts, I.C.; Hollman, P.C. Polyphenols and disease risk in epidemiologic studies. Am. J. Clin. Nutr. 2005, 81, 317S$325 \mathrm{~S}$.

162. Tsuda, T.; Horio, F.; Uchida, K.; Aoki, H.; Osawa, T.; Dietary cyanidin 3-O- $\beta$-D-glucoside-rich purple corn color prevents obesity and ameliorates hyperglycemia in mice. J. Nutr. 2003, 133, 2125-2130.

163. Garg, M.; Chawla, M.; Chunduri, V.; Kumar, R.; Sharma, S.; Sharma, N.K.; Kaur, N.; Kumar, A.; Mundey, J.K.; Saini, M.K.; Singh, S.P. Transfer of grain colors to elite wheat cultivars and their characterization. J. Cereal Sci. 2016, $71,138-144$.

164. Dobrovolskaya, O.; Arbuzova, V.S.; Lohwasser, U.; Röder, M.S.; Börner, A. Microsatellite mapping of complementary genes for purple grain colour in bread wheat (Triticum aestivum) L. Euphytica. 2006, 150, 355-364.

165. Khlestkina, E.K.; Röder, M.S.; Börner, A. Mapping genes controlling anthocyanin pigmentation on the glume and pericarp in tetraploid wheat (Triticum durum L.). Euphytica. 2010, 171, 65-69.

166. Tereshchenko, O.; Gordeeva, E.; Arbuzova, V.; Börner, A.; Khlestkina, E. The D genome carries a gene determining purple grain colour in wheat. Cereal Res. Commun. 2012, 40, 334-341.

167. Gordeeva, E.I.; Shoeva, O.Y.; Khlestkina, E.K. Marker-assisted development of bread wheat near-isogenic lines carrying various combinations of purple pericarp (Pp) alleles. Euphytica. 2015, 203, 469-476.

168. Liu, D.; Li, S.; Chen, W.; Zhang, B.; Liu, D.; Liu, B.; Zhang, H. Transcriptome analysis of purple pericarps in common wheat (Triticum aestivum L.). PIOS ONE. 2016, 11, e0155428.

169. Shoeva, O.; Gordeeva, E.; Khlestkina, E. The regulation of anthocyanin synthesis in the wheat pericarp. Molecules. 2014, 19, 20266-20279.

170. Zong, Y.; Xi, X.; Li, S.; Chen, W.; Zhang, B.; Liu, D.; Liu, B.; Wang, D. and Zhang, H. Allelic variation and transcriptional isoforms of wheat TaMYC1 gene regulating anthocyanin synthesis in pericarp. Front. Plant Sci. 2017, 8, 1645. 
171. Li, N.; Zong, Y.; Liu, B.L.; Chen, W.J.; Zhang, B. TaMYB3, encoding a functional MYB transcriptor, isolated from the purple pericarp of Triticum aestivum. Cereal Res. Commun. 2017, 45, 369-380.

172. Jiang, W.; Liu, T.; Nan, W.; Jeewani, D.C.; Niu, Y.; Li, C.; Wang, Y.; Shi, X.; Wang, C.; Wang, J.; Li, Y. Two transcription factors TaPpm1 and TaPpb1 co-regulate anthocyanin biosynthesis in purple pericarps of wheat. J. Exp. Bot. 2018, 69, 2555-2567.

173. Burešová, V.; Kopecký, D.; Bartoš, J.; Martinek, P.; Watanabe, N.; Vyhnánek, T.; Doležel, J. Variation in genome composition of blue-aleurone wheat. Theor. Appl. Genet. 2015, 128, 273-282.

174. Martinek, P.; Jirsa, O.; Vaculová, K.; Chrpová, J.; Watanabe, N.; Burešová, V.; Kopecký, D.; Štiasna, K.; Vyhnánek, T.; Trojan, V. Use of wheat gene resources with different grain colour in breeding. Proceedings of the Tagungsband der, 64. 2014, 1, 75-78.

175. Sharma, S.; Chunduri, V.; Kumar, A.; Kumar, R.; Khare, P.; Kondepudi, K.K.; Bishnoi, M.; Garg, M. Anthocyanin bio-fortified colored wheat: Nutritional and functional characterization. PloS one. 2018. 13, p.e0194367. 